\title{
Effects of supplementation with ruminally protected choline on performance of multiparous Holstein cows did not depend upon prepartum caloric intake
}

\author{
M. G. Zenobi, R. Gardinal, ${ }^{1}$ J. E. Zuniga, ${ }^{2}$ A. L. G. Dias, ${ }^{3}$ C. D. Nelson, J. P. Driver, B. A. Barton, ${ }^{4}$ \\ J. E. P. Santos, and C. R. Staples ${ }^{5}$ \\ Department of Animal Sciences, University of Florida, Gainesville 32611
}

\begin{abstract}
Objectives were to evaluate the effect of prepartum energy intake on performance of dairy cows supplemented with or without ruminally protected choline (RPC; 0 or $17.3 \mathrm{~g} / \mathrm{d}$ of choline chloride; 0 or $60 \mathrm{~g} / \mathrm{d}$ of ReaShure, Balchem Corp., New Hampton, NY). At 47 $\pm 6 \mathrm{~d}$ before the expected calving date, 93 multiparous Holstein cows were assigned randomly to 1 of 4 dietary treatments in a $2 \times 2$ factorial arrangement. Cows were fed energy to excess [EXE; $1.63 \mathrm{Mcal}$ of net energy for lactation/kg of dry matter (DM)] or to maintenance (MNE; 1.40 Mcal of net energy for lactation $/ \mathrm{kg}$ of DM) in ad libitum amounts throughout the nonlactating period. The RPC was top-dressed for $17 \pm 4.6 \mathrm{~d}$ prepartum through $21 \mathrm{~d}$ postpartum $(\mathrm{PP})$. After calving, cows were fed the same methionine-balanced diet, apart from RPC supplementation, through 15 wk PP. Liver was biopsied at $-14,7,14$, and $21 \mathrm{~d}$ relative to parturition. Cows fed EXE or MNE diets, respectively, consumed 40 or $10 \%$ more $\mathrm{Mcal} / \mathrm{d}$ than required at 15 $\mathrm{d}$ before parturition. Cows fed the MNE compared with the EXE diet prepartum consumed $1.2 \mathrm{~kg} / \mathrm{d}$ more DM postpartum but did not produce more milk (41.6 vs. $43.1 \mathrm{~kg} / \mathrm{d})$. Thus, PP cows fed the EXE diet prepartum were in greater mean negative energy balance, tended to have greater mean concentrations of circulating insulin, fatty acids, and $\beta$-hydroxybutyrate, and had greater triacylglycerol in liver tissue ( 8.3 vs. $10.7 \%$ of DM) compared with cows fed the MNE diet prepartum. Cows fed RPC in transition tended to produce more milk (43.5 vs. $41.3 \mathrm{~kg} / \mathrm{d}$ ) and energy-corrected milk (44.2 vs. $42.0 \mathrm{~kg} / \mathrm{d})$ without increasing DM intake (23.8

\footnotetext{
Accepted October 26, 2017.

${ }^{1}$ Current address: Department of Animal Nutrition and Production,

${ }^{2}$ Current address: San Isidro, Perez Zeledón, San José, Costa Rica.

${ }^{3}$ Current address: Department of Agricultural, Food and Nutritional

${ }^{5}$ Corresponding author: chasstap@ufl.edu
}

Received June 13, 2017. University of Sao Paulo, 13635-900, Pirassununga, Brazil. Science, University of Alberta, Edmonton, AB, T6G 2P5, Canada.

${ }^{4}$ Current address: 52 Sunrise Park Rd, Balchem Corp., New Hampton, NY.
\end{abstract}

vs. $23.2 \mathrm{~kg} / \mathrm{d}$ ) during the first $15 \mathrm{wk} \mathrm{PP}$, and tended to produce more milk over the first $40 \mathrm{wk}$ PP (37.1 vs. $35.0 \mathrm{~kg} / \mathrm{d}$ ). Energy balance of cows fed RPC was more negative at wk 2,3 , and $6 \mathrm{PP}$, but mean circulating concentrations of fatty acids and $\beta$-hydroxybutyrate did not differ from those of cows not fed RPC. Despite differences in energy balance at 2 and 3 wk PP, mean concentration of hepatic triacylglycerol did not differ between RPC treatments. Feeding RPC reduced the daily prevalence of subclinical hypocalcemia from 25.5 to $10.5 \%$, as defined by concentrations of total $\mathrm{Ca}$ of $<8.0 \mathrm{mg} / \mathrm{dL}$ in serum in the first $7 \mathrm{~d} \mathrm{PP}$. Pregnancy at first artificial insemination tended to be greater for cows fed RPC (41.3 vs. 23.6\%), but the proportion of pregnant cows did not differ by 40 wk PP. Heifers born from singleton calvings from cows fed RPC tended to experience greater daily gain between birth and $50 \mathrm{wk}$ of age than heifers from cows not supplemented with RPC. Feeding RPC for approximately $38 \mathrm{~d}$ during the transition period tended to increase yield of milk for 40 wk regardless of amount of energy consumed during the pregnant, nonlactating period.

Key words: choline, wheat straw, fatty liver, hypocalcemia

\section{INTRODUCTION}

For decades, farmers and scientists have been aware of the dangers of calving dairy cows with excess subcutaneous fat, also known as overconditioned cows, on their subsequent performance (Morrow, 1976). Negative consequences of overconditioned cows at calving have included reduced DMI, fatty liver, less milk production, increased metabolic problems, and poor reproductive performance (Drackley, 1999). The presence of overconditioned cows (BCS >3.75) on farms is likely less of a problem today than in the latter part of the 20th century. However, excessive intake of calories by nonlactating cows can lead to accumulation of body fat that is hidden from view (omental, mesenteric, and prerenal fat; Drackley et al., 2014), such that BCS was unchanged, although Drackley et al. (2014) did not 
report carcass fat that included subcutaneous fat. This may cause managers to be content that their cows will not experience the negative effects of overconditioning on postpartum performance because BCS is within industry recommendations. Although it remains to be determined whether greater accumulation of visceral fat around parturition may have subsequent negative effects on performance, overconsumption of calories during the entire dry period compared with feeding to maintenance led to increased concentrations of plasma fatty acids (Janovick et al., 2011; Graugnard et al., 2013; Mann et al., 2015) and BHB (Janovick et al., 2011; Mann et al., 2015), and increased concentration of triacylglycerol (TAG) in liver (Janovick et al., 2011; Graugnard et al., 2013) without changing yield of milk (Graugnard et al., 2013; Mann et al., 2015). If cows are overfed calories only during the last $3 \mathrm{wk}$ of gestation (close-up period), a common current practice, negative results can occur postpartum, including greater loss of BW (Zhang et al., 2015) and a more rapid increase in hepatic TAG (Ji et al., 2012).

Choline is classified as a quasivitamin because it does not fit the classical definition of a vitamin in that it is not identified as being needed as an enzyme cofactor, it is required in gram rather than in milligram quantities by nonruminants, and, unlike $\mathrm{B}$ vitamins, it becomes an integral part of the structural component of tissues [e.g., phosphatidylcholine (PC) in cell wall membranes; Zeisel, 1991]. Choline is a major lipotropic compound in mammals in that it promotes the export of fat from the liver as part of very low density lipoproteins. Indeed, lactating dairy cows supplemented with ruminally protected choline (RPC) chloride around the time of parturition have experienced a reduction in concentration of hepatic TAG (Santos and Lima, 2009; Zom et al., 2011; Elek et al., 2013). This lipotropic effect of choline has been suggested as the main mechanism to help explain the frequent improvement in yield of milk by cows supplemented with RPC around parturition (Shahsavari et al., 2016).

Overfeeding energy during the entire dry period should increase hepatic concentrations of TAG. Therefore, the aim of the present experiment was to evaluate the effect of supplementation with RPC on performance of multiparous cows that have been fed calories to meet or greatly exceed requirements during the entire dry period. Our hypothesis was supplementation of RPC in the periparturient period would preferentially benefit those multiparous dairy cows that were more prone to develop fatty liver postpartum; that is, those overconsuming calories in the prepartum period. An interaction of prepartum caloric intake by RPC supplementation was expected. A second aim was to evaluate the effect of energy density of the prepartum diet and RPC sup- plementation to dams in late lactation on the growth rate of their female offspring from birth to yearling age.

\section{MATERIALS AND METHODS}

\section{Cows and Dietary Treatments}

The experiment was conducted at the University of Florida dairy farm from November 2014 to September 2015. All procedures involving cows in the experiment were carried out according to the University of Florida's Institutional Animal Care and Use Committee.

At $47 \pm 6$ d before the expected calving date, pregnant, nonlactating Holstein cows with at least 1 previous lactation $(\mathrm{n}=109)$ were enrolled in the experiment. Selection criteria included apparently healthy cows with no history of chronic disease before enrollment and a 305-d mature equivalent milk yield greater than $6,800 \mathrm{~kg}$. For cows that completed the study ( $\mathrm{n}=93$ ), the mean \pm standard deviation for BW and BCS (Elanco Animal Health, 2009) were 735 $\pm 90 \mathrm{~kg}$ and $3.54 \pm 0.33$, respectively, at the time of enrollment. Cows were assigned randomly to 1 of 4 treatments in a $2 \times 2$ factorial arrangement. One factor was RPC fed at $0(-\mathbf{R P C})$ or $17.3 \mathrm{~g} / \mathrm{d}$ of choline chloride $(+\mathbf{R P C})$ per cow from $21 \mathrm{~d}$ before expected calving date through $21 \mathrm{~d}$ postpartum. The choline chloride was fed as part of $60 \mathrm{~g} / \mathrm{d}$ of ReaShure (Balchem Corp., New Hampton, NY). The RPC was mixed with ground corn and dried molasses in a 30:56:14 ratio (as-is basis) and top-dressed (200 g/d) onto the TMR fed to individual cows once daily. Cows assigned to the - RPC treatment received $200 \mathrm{~g} / \mathrm{d}$ of a top-dressing of ground corn and dried molasses in an 80:20 ratio (as-is basis). The second factor was prepartum diets formulated to 1.63 (excess energy; EXE) or 1.40 (maintenance energy; MNE) Mcal of $\mathrm{NE}_{\mathrm{L}} / \mathrm{kg}$ of dietary DM fed in ad libitum amounts (Table 1). Therefore, the 4 treatments were EXE intake without or with RPC and MNE intake without or with RPC. Adjusting the proportions of corn silage, triticale silage, and chopped wheat straw in the 2 prepartum diets largely accounted for the differences in $\mathrm{NE}_{\mathrm{L}}$ concentration (Table 1). The major difference between the far-off and close-up diets was the inclusion of an acidogenic product (Biochlor; Arm and Hammer Animal Nutrition, Princeton, NJ) in the close-up diets to create diets with negative DCAD values (Table 2 ).

\section{Feeding Management and Chemical Analyses}

After calving, cows were fed the same diet (Tables 1 and 2), apart from RPC supplementation, through 15 wk PP. From dry off to 25 d before expected calv- 
ing date, cows were grouped separately, according to energy treatment, in outdoor pens with free access to feed, shade, and water. Starting at $24 \mathrm{~d}$ before expected calving date, cows were relocated and grouped into 1 outdoor pen equipped with shade and fans, as well as sprinklers over the feeding area. Each cow was assigned randomly and trained (24 to $22 \mathrm{~d}$ before calving) to an individual feeding gate (Calan Broadbent feeding system, American Calan Inc., Northwood, NH). Within $6 \mathrm{~h}$ after calving, cows were moved to an open-sided freestall barn with sand-bedded stalls with fans mounted above the beds and a water sprinkler line in the feed bunk area for cooling of cows. Cows were assigned and trained to an individual feeding gate (American Calan Inc.). Cows fully learned to open their assigned Calan gate within $1 \mathrm{~d}$ postpartum.

Wheat straw was purchased in 35-kg bales (Quality Hay Sales Inc., Willison, FL), stored in a closed container on farm, and chopped to a particle length of $\leq 5$ $\mathrm{cm}$ as needed for the TMR. Methionine was formulated to be approximately $2.3 \%$ of MP according to NRC (2001) in both prepartum and postpartum diets. All diets were fed as a TMR once daily at $0930 \mathrm{~h}$ during the prepartum period and twice daily at 0730 and 1100

Table 1. Ingredient composition of diets fed during the far-off, close-up, and lactating periods

\begin{tabular}{|c|c|c|c|c|c|}
\hline \multirow[b]{2}{*}{ Ingredient, $\%$ of DM } & \multicolumn{2}{|c|}{ Far-off diet ${ }^{1}$} & \multicolumn{2}{|c|}{ Close-up diet ${ }^{2}$} & \multirow{2}{*}{$\begin{array}{c}\text { Lactating } \\
\text { diet }\end{array}$} \\
\hline & $\mathrm{EXE}^{3}$ & $\mathrm{MNE}^{4}$ & EXE & MNE & \\
\hline Corn silage & 58.3 & 22.1 & 58.3 & 23.3 & 45.2 \\
\hline Wheat straw & 8.3 & 40.4 & 8.3 & 37.5 & - \\
\hline Triticale silage & - & 6.2 & - & 5.8 & - \\
\hline Brewers grains, wet & 16.7 & 16.7 & 16.7 & 16.7 & - \\
\hline Citrus pulp, dried & - & - & 6.9 & 3.3 & 6.0 \\
\hline Canola meal, pelleted & 6.2 & 10.8 & 2.1 & 7.4 & - \\
\hline Mineral-vitamin premix ${ }^{5}$ & 3.8 & 3.8 & - & - & - \\
\hline Mineral-vitamin premix $^{6}$ & - & - & 4.2 & 4.2 & \\
\hline Biochlor $^{7}$ & - & - & 3.5 & 1.8 & - \\
\hline Corn, ground & - & - & - & - & 14.0 \\
\hline Soybean hulls & 6.7 & - & - & - & 8.0 \\
\hline Soybean meal & - & - & - & - & 15.2 \\
\hline Whole cottonseed & - & - & - & - & 8.0 \\
\hline Mineral-vitamin premix $^{8}$ & - & - & - & - & 3.6 \\
\hline
\end{tabular}

${ }^{1}$ Diets differing in energy were fed from $47 \pm 6$ to $17.0 \pm 4.6 \mathrm{~d}$ before calving.

${ }^{2}$ Diets differing in energy were fed from $17 \pm 4.6 \mathrm{~d}$ before calving until the day of calving.

${ }^{3} \mathrm{EXE}=$ excess energy. Diet formulated to supply energy in great excess of cow's requirement for maintenance and pregnancy (NRC, 2001).

${ }^{4} \mathrm{MNE}=$ maintenance energy. Diet formulated to supply energy in slight excess of cow's requirement for maintenance and pregnancy (NRC, 2001).

${ }^{5}$ Contained (DM basis) $39.5 \%$ wheat bran, $20.8 \%$ calcium carbonate, $20.8 \%$ sodium chloride, $14.6 \%$ magnesium oxide, $2.8 \%$ vitamins A, D, and E, 2.0\% ClariFly Livestock Premix 0.67\% (Central Garden \& Pet Co., Schaumburg, IL), 0.6\% Sel-Plex 2000 (Alltech Biotechnology, Nicholasville, KY), 0.52\% Rumensin 90 (Elanco Animal Health, Greenfield, IN), 0.36\% IntelliBond Vital 4 (Micronutrients USA LLC, Indianapolis, IN), and $0.002 \%$ EDDI $80 \%$. Each kilogram contained $3.6 \%$ CP, $8.4 \%$ Ca, 0.4\% P, 8.0\% Mg, $0.5 \%$ K, 0.07\% S, 8.2\% $\mathrm{Na}, 12.7 \% \mathrm{Cl}, 98 \mathrm{mg}$ of Fe, $965 \mathrm{mg}$ of Zn, $204 \mathrm{mg}$ of Cu, $785 \mathrm{mg}$ of $\mathrm{Mn}, 13 \mathrm{mg}$ of Se, $11 \mathrm{mg}$ of Co, $18 \mathrm{mg}$ of I, $227 \mathrm{kIU}$ of vitamin A, $76 \mathrm{kIU}$ of vitamin D, 2,267 IU of vitamin E, 1,034 $\mathrm{mg}$ of monensin, and $187 \mathrm{mg}$ of diflubenzuron.

${ }^{6}$ Contained (DM basis) $62.7 \%$ corn gluten feed, $15.7 \%$ magnesium sulfate $\times 7 \mathrm{H}_{2} \mathrm{O}, 8.9 \%$ calcium carbonate, $6.7 \%$ magnesium oxide, $2.2 \%$ sodium chloride, $2.0 \%$ ClariFly Livestock Premix 0.67\% (Central Garden \& Pet Co.), $0.67 \%$ vitamin E 500,000 kIU $/ \mathrm{kg}, 0.45 \%$ Sel-Plex 2000 (Alltech Biotechnology), 0.38\% Rumensin 90 (Elanco Animal Health), 0.27\% IntelliBond Vital 4 (Micronutrients USA LLC), 0.036\% vitamin A concentrate $650,000 \mathrm{kIU} / \mathrm{kg}, 0.013 \%$ vitamin D concentrate $500,000 \mathrm{kIU} / \mathrm{kg}$, and $0.002 \%$ EDDI $80 \%$. Each kilogram contained $13.5 \% \mathrm{CP}, 3.7 \% \mathrm{Ca}, 0.9 \% \mathrm{P}, 5.5 \% \mathrm{Mg}, 0.9 \% \mathrm{~K}, 2.3 \% \mathrm{~S}, 1.0 \% \mathrm{Na}, 1.6 \% \mathrm{Cl}, 151 \mathrm{mg}$ of $\mathrm{Fe}, 724 \mathrm{mg}$ of $\mathrm{Zn}$, $165 \mathrm{mg}$ of $\mathrm{Cu}, 543 \mathrm{mg}$ of $\mathrm{Mn}, 9 \mathrm{mg}$ of Se, $4 \mathrm{mg}$ of Co, $16 \mathrm{mg}$ of I, $233 \mathrm{kIU}$ of vitamin A, $67 \mathrm{kIU}$ of vitamin D, 3,362 IU of vitamin E, $748 \mathrm{mg}$ of monensin, and $139 \mathrm{mg}$ of diflubenzuron.

${ }^{7}$ Arm \& Hammer Animal Nutrition, Princeton, NJ.

${ }^{8}$ Contained (DM basis) 29.9\% sodium bicarbonate, 19.9\% LysAAMet (Perdue Venture Milling, Salisbury, MD), 14.3\% DCAD Plus (Arm \& Hammer Animal Nutrition), 13.2\% calcium carbonate, $7.7 \%$ magnesium oxide, $6.6 \%$ dicalcium phosphate, $6.6 \%$ sodium chloride, $1.0 \%$ vitamins A, D, and E, ClariFly Livestock Premix 0.67\% (Central Garden \& Pet Co.), 0.39\% Sel-Plex 2000 (Alltech Biotechnology), 0.22\% IntelliBond Vital 4 (Micronutrients USA LLC), 0.22\% Rumensin 90 (Elanco Animal Health), and 0.002\% EDDI 80\%. Each kilogram contained $18.2 \% \mathrm{CP}, 6.5 \% \mathrm{Ca}, 1.3 \% \mathrm{P}, 4.2 \% \mathrm{Mg}, 7.0 \% \mathrm{~K}, 10.6 \% \mathrm{Na}, 4.0 \% \mathrm{Cl}, 0.2 \% \mathrm{~S}, 1,053 \mathrm{mg}$ of $\mathrm{Fe}$, $566 \mathrm{mg}$ of $\mathrm{Zn}, 132 \mathrm{mg}$ of Cu, $470 \mathrm{mg}$ of $\mathrm{Mn}, 7.8 \mathrm{mg}$ of Se, $3.9 \mathrm{mg}$ of Co, $13.0 \mathrm{mg}$ of I, $157 \mathrm{kIU}$ of vitamin A, 34 $\mathrm{kIU}$ of vitamin D, 1,145 IU of vitamin E, $441 \mathrm{mg}$ of monensin, and $66 \mathrm{mg}$ of diflubenzuron. 
Table 2. Chemical composition of diets (mean $\pm \mathrm{SD}$ ) fed during the far-off, close-up, and lactating periods

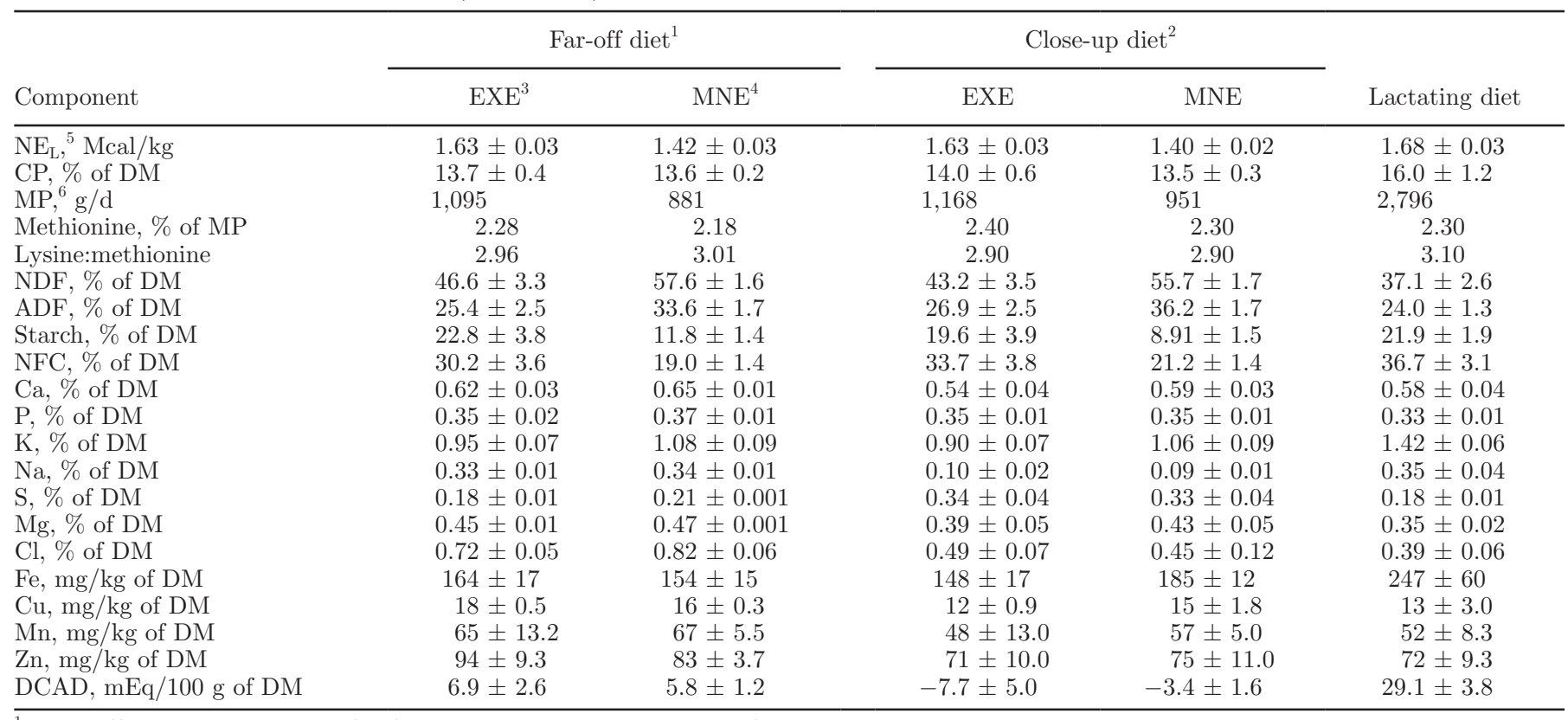

${ }^{1}$ Diets differing in energy were fed from $47 \pm 6 \mathrm{~d}$ to $17.0 \pm 4.7 \mathrm{~d}$ before calving.

${ }^{2}$ Diets differing in energy were fed from $17.0 \pm 4.6 \mathrm{~d}$ before calving until the day of calving.

${ }^{3} \mathrm{EXE}=$ excess energy. Diet formulated to supply energy in great excess of cow's requirement for maintenance and pregnancy (NRC, 2001). ${ }^{4} \mathrm{MNE}=$ maintenance energy. Diet formulated to supply energy in slight excess of cow's requirement for maintenance and pregnancy (NRC, 2001).

${ }^{5}$ Calculated using NRC (2001) equations.

${ }^{6}$ Calculated for actual DMI using NRC (2001) software.

$\mathrm{h}$ during the postpartum period. The amount of TMR offered to individual cows was adjusted daily to result in 2 to $5 \%$ refusals. Refusals were weighed once daily before the first morning feeding. For nonlactating and lactating cows, the TMR was pushed toward cows to allow easy consumption every $30 \mathrm{~min}$ or as needed during the first $2 \mathrm{~h}$ after feedings, every $2 \mathrm{~h}$ up to $1800 \mathrm{~h}$, and, lastly, after cows were milked at night.

Nonforage feedstuffs (except wet brewer's grains) were mixed in 1,800-kg batches and stored in metal bins to serve as concentrate mixes. Wheat straw and wet feeds were sampled every $3 \mathrm{~d}$, whereas concentrate mixtures were sampled weekly, dried at $55^{\circ} \mathrm{C}$ for $48 \mathrm{~h}$ in a forced-air oven, and dry weight was recorded. Dried individual feed samples were ground to pass a 1-mm screen of a Wiley mill (Thomas Scientific, Swedesboro, NJ). Dried, ground feed samples were composited monthly and analyzed using wet chemistry procedures (AOAC methods; Dairyland Laboratories Inc., Arcadia, WI). The daily DMI of individual cows were calculated based on DM of individual feeds measured at $105^{\circ} \mathrm{C}$. The forage-to-concentrate ratios of the TMR (as-fed basis) fed were adjusted every $3 \mathrm{~d}$ using the rolling average of the $\mathrm{DM}$ values $\left(105^{\circ} \mathrm{C}\right)$ of the wet feeds and concentrate mixes.

\section{Cow and Calf Measurements}

Average daily gain was determined for female calves using BW at birth, weaning ( $8 \mathrm{wk}$ ), and $50 \mathrm{wk}$ of age. Calves were weighed within $2 \mathrm{~h}$ of birth and before feeding of colostrum (>50 g/L of $\mathrm{IgG})$. A complete grain starter was offered in ad libitum amounts during the first $8 \mathrm{wk}$ of life. The weaning process involved reducing milk consumption from $3 \mathrm{~L}$ twice daily to $3 \mathrm{~L}$ once daily at 6 wk of age, removal of milk from the diet at 7 wk of age, and movement of heifers from single to group housing on pasture at $61.1 \pm 3.3 \mathrm{~d}$ of age. Body weights were measured on the day of moving to group housing. Upon weaning, heifers were offered only starter for 2 wk. A silage-based TMR in ad libitum amounts was offered thereafter through 50 wk of age. Body weight was measured in the morning before feeding of TMR at $350.0 \pm 2.2 \mathrm{~d}$ of age.

Colostrum yield was recorded automatically (AfiFlo milk meters, S.A.E. Afikim, Israel) as the first milking postpartum and a representative sample was collected and tested for Brix units using a digital refractometer (MA871; Milwaukee Instruments Inc., Rocky Mount, NC). Brix units (\%) were converted to $\operatorname{IgG}(\mathrm{g} / \mathrm{L})$ based on the equation reported by Bielmann et al. (2010). 
Yield of milk was recorded automatically (AfiFlo milk meters) at 1000 and $2200 \mathrm{~h}$. Samples of milk were collected once weekly in 2 sequential milkings for measurements of fat, true protein, lactose, and SCC. Bronopol-B-14 (Advanced Instruments, Norwood, MA) was used as a preservative and samples were sent within a day of collection to Southeast Milk dairy laboratory (Belleview, FL) for analysis of butterfat, true protein, lactose, and solids using a Bentley 2000 infrared component analyzer (Bentley Instruments Inc., Chaska, $\mathrm{MN})$. Concentration of somatic cells was determined using a Bentley 500 Somacount flow cytometer (Bentley Instruments Inc.). Milk yield from each sampling was used to calculate the final concentration of milk components. Production of $3.5 \%$ FCM and ECM $(\mathrm{kg} / \mathrm{d})$ was calculated using the following equations:

$$
\begin{gathered}
3.5 \% \mathrm{FCM}=(0.4324 \times \text { milk }, \mathrm{kg} / \mathrm{d}) \\
+(16.218 \times \text { milk fat }, \mathrm{kg} / \mathrm{d}), \text { and } \\
\mathrm{ECM}=(0.3246 \times \text { milk, } \mathrm{kg} / \mathrm{d})+(12.86 \times \text { milk fat }, \\
\mathrm{kg} / \mathrm{d})+(7.04 \times \text { milk protein, } \mathrm{kg} / \mathrm{d})(\text { Orth, } 1992) .
\end{gathered}
$$

During the prepartum period, BW and BCS were taken using increments of 0.25 units (Elanco Animal Health, 2009) by the same 2 trained individuals at dry off and the day of transfer to Calan gates. During the postpartum period cows were weighed twice daily on a walk-though scale (AfiWeigh, S.A.E. Afikim) located in the exit lane of the milking parlor. Body condition was scored at calving and 2, 4, 7, 10, and 15 wk postpartum as described previously. Energy balance (EB) was calculated according to NRC (2001).

Blood was collected at 12 and $7 \mathrm{~d}$ before expected calving and at $0,1,3,7,14,21$, and $35 \mathrm{~d}$ postpartum by puncture of the coccygeal vessels into evacuated tubes (Vacutainer, Becton Dickinson, Franklin Lakes, NJ) containing lithium heparin and placed on ice. Within 30 min of collection, cold samples were centrifuged at $1,125 \times g$ for $15 \mathrm{~min}$ at room temperature, plasma was harvested, and multiple aliquots of $1.5 \mathrm{~mL}$ were frozen at $-30^{\circ} \mathrm{C}$ until analysis.

Samples collected at $-12,-7,0,7,14,21$, and $35 \mathrm{~d}$ relative to calving were analyzed for BHB, fatty acids, plasma urea $\mathrm{N}$, glucose, and insulin to assess energy status of the cows. Each run included a common control sample. A Technicon Autoanalyzer (Technicon Instruments Corp., Chauncey, NY) was used to measure concentrations of plasma glucose (Bran and Luebbe Industrial Method 339-19; Gochman and Schmitz, 1972) and urea N (Bran and Luebbe Industrial Method 339-01; Marsh et al., 1965)] in duplicate. Inter- and intra-assay coefficients of variation were 1.9 and $0.7 \%$ for glucose and 2.2 and $1.0 \%$ for plasma urea N, respectively. Concentrations of fatty acids (NEFA-C kit; Wako Diagnostics Inc., Richmond, VA; as modified by Johnson and Peters, 1993) and BHB (Wako Autokit 3-HB; Wako Diagnostics Inc.) were determined in duplicate. Inter- and intra-assay coefficients of variation were 4.4 and $4.7 \%$ and 10.8 and $7.8 \%$ for fatty acids and BHB, respectively. Concentrations of insulin were analyzed using an ELISA kit (Mercodia Bovine Insulin ELISA, Mercodia Inc., Uppsala, Sweden); inter- and intra-assay coefficients of variation were 9.2 and $16.4 \%$, respectively. Total $\mathrm{Ca}(\mathbf{t C a})$ was determined on plasma of blood collected at $0,1,3$, and 7 DIM using an atomic absorption spectrophotometer (AAnalyst 200, PerkinElmer Inc., Waltham, MA) with the flame technique and acetylene gas; inter- and intra-assay coefficients of variation were 1.2 and $0.5 \%$, respectively.

Samples of liver tissue (0.5 to $1.5 \mathrm{~g}$ wet weight) were collected at $-9.0 \pm 4.4,7,14$, and 21 DIM using a stainless steel percutaneous liver biopsy tool (Aries Surgical, Davis, CA). An area between the 11th and 13 th rib was scanned by ultrasound (Aloka SSD-500V equipped with a $3.5-\mathrm{MHz}$ convex transducer, Aloka Co. Ltd., Tokyo, Japan) to determine the optimal intercostal location for liver tissue collection. After rinsing with sterile saline, liver was sliced into 3 sections, transferred into 3 cryovials, snap-frozen in liquid $\mathrm{N}$, and stored at $-80^{\circ} \mathrm{C}$ until analysis for TAG in triplicate. For analysis, samples were thawed on ice, blotted dry, and approximately $0.1 \mathrm{~g}$ of tissue was homogenized in $1 \mathrm{~mL}$ of saline in triplicate using an Ultra-Turrax T25 homogenizer (Rose Scientific Ltd., Edmonton, AB, Canada). After addition of $2 \mathrm{~mL}$ of 1:1 saline:methanol, samples were split into 3 aliquots. Dry matter was determined from $0.5 \mathrm{~mL}$ of homogenized liver sample by drying for 48 $\mathrm{h}$ in a $55^{\circ} \mathrm{C}$ forced-air oven. A second aliquot was analyzed for TAG (Folch et al., 1957) using a colorimetric assay (Foster and Dunn, 1973). A third aliquot was used to measure DNA content of the sample (Labarca and Paigen, 1980).

\section{Definition and Diagnosis of Dystocia, Retained Fetal Membranes, Metritis, and Other Diseases}

Dystocia was defined as calving assistance required for $>15$ min. Retained fetal membranes was declared when a cow failed to expel the fetal membranes within $24 \mathrm{~h}$ after parturition. The criteria used to identify cows for a health assessment throughout the experiment included inappetence at the morning feeding, milk yield deviation $>15 \%$ compared with the previous day, and intervals between meals of $>4 \mathrm{~h}$ during daylight hours. 
Because the TMR for each cow was pushed up into a mound every hour, the disturbance of that mound was evidence of a meal. A complete physical examination, including rectal temperature and urine sample, was performed at 4,7 , and 12 DIM for diagnosis of disease; cows with a rectal temperature $\geq 39.5^{\circ} \mathrm{C}$ were considered febrile. Diagnosis of metritis was based on a fetid watery discharge from the vagina and an enlarged uterus irrespective of rectal temperature. Fever concurrent with metritis was indicative of puerperal metritis. Milk fever was diagnosed based on clinical sigs of recumbency or inability to rise. Subclinical hypocalcemia (SCH) was defined as plasma tCa concentrations of $<8.0 \mathrm{mg} / \mathrm{dL}$ (Reinhardt et al., 2011) at 0 (day of parturition), 1, 3, or 7 DIM. Hyperketonemia was defined as concentrations of plasma BHB $\geq 1.2 \mathrm{~m} M$ for at least 1 d from 1 to 21 DIM (Oetzel, 2004). Cows diagnosed as having moderate $(\sim 0.4 \mathrm{mM})$ or large ketone concentrations $(>0.8 \mathrm{mM})$ in urine were considered to have clinical ketosis (URS-1K, Teco Diagnostics, Anaheim, CA). In addition to 4, 7, and 12 DIM, urine was sampled if a cow was suspected of having ketosis. Diagnosis of clinical ketosis resulted in treatment with $500 \mathrm{~mL}$ of propylene glycol or intravenous infusion of $250 \mathrm{~mL}$ of $50 \%$ dextrose solution and 10 to $20 \mathrm{~mL}$ of a vitamin B complex, concurrent with an oral drench (Van Beek Natural Sci, Orange City, IA). Cows with moderate or severe ketosis for $3 \mathrm{~d}$ received an additional treatment of $10 \mathrm{~mL}$ of dexamethasone i.v. or i.m on $\mathrm{d} 3$ and veterinary consult. Mastitis was defined as visible abnormalities in the milk or udder with or without systemic symptoms. Other disorders or diseases diagnosed included digestive problems (indigestion and displaced abomasum) and respiratory disease. Cows were removed from the experiment when failing to recover from a clinical disorder after treatment or surgery. Six, 2,2 , and 6 cows were removed from the experiment representing treatments EXE - RPC, EXE + RPC, MNE - RPC, and MNE +RPC, respectively (Table 3) and were not included in the statistical analyses.

Vaginal discharge was collected at $21 \pm 1$ and $40 \pm 1$ DIM using the Metricheck device (Kiwikit Ltd., Wales, New Zealand) and scored according to Sheldon et al. (2006). Cows having a vaginal discharge score $>2$ were classified as having purulent vaginal discharge (Dubuc et al., 2010). Additionally, subclinical endometritis was assessed at $40 \pm 1$ DIM using the cytobrush technique (Lima et al., 2013). After sample collection, the cytobrush was rolled onto a slide and later stained using the Diff-Quick stain kit (IMEB, San Marcos, CA). Two technicians blinded to treatments read the slides. Two hundred cells were counted on each slide using a microscope at $400 \times$ magnification to determine the proportion of PMNL relative to the total leukocytes and endometrial cells. Cows with a proportion of PMNL $>5 \%$ were classified as having subclinical endometritis (Gilbert et al., 2005).

\section{Reproductive Management and Reproductive Responses}

Cows were subjected to synchronization of the estrous cycle and ovulation using a double Ovsynch protocol (Ribeiro et al., 2012). Estrous cyclicity was evaluated at $26 \pm 3$ and $40 \pm 3$ DIM by ultrasonographic examination of the ovaries using a portable ultrasound scanner equipped with a $7.5-\mathrm{MHz}$ transrectal probe (Easi-Scan, BCF Technology, Rochester, MN). Cows without a corpus luteum $>15 \mathrm{~mm}$ during both examinations were considered anovular. Pregnancy per AI (P/AI) was diagnosed by ultrasonography on d 60 after insemination. Days in milk were recorded for first AI, P/AI at first AI, and P/AI to all AI performed during the first 210 DIM.

\section{Statistical Analyses}

Experiment was a randomized, complete block design with a $2 \times 2$ factorial arrangement of treatments. Cow was the experimental unit and considered random. Block was considered random. At the time of treatment assignment, prepartum cows were blocked by BCS and mature equivalent 305-d milk yield and, within each block, assigned randomly to 1 of the 4 treatments weekly. Pre- and postpartum data were analyzed separately using the MIXED procedure of SAS version 9.4 (SAS/ STAT, SAS Institute Inc., Cary, NC). The REPEATED statement was used for dependent variables measured over time. Model included the fixed effects of energy intake prepartum (EXE vs. MNE), RPC intake (without vs. with), interaction between energy intake prepartum and RPC intake, day or week of measurement, and all 2- and 3-way interactions. Cow was nested within treatment and was the error term for testing the effects of treatment. The covariance structure with the lowest Akaike's information criterion was selected for each variable and spatial power was the covariance structure of choice when intervals between times of sampling were not spaced evenly. When an interaction with time was detected as significant, treatment means at time points of measure were partitioned using the SLICE command of SAS.

For data collected at single time points only, the MIXED procedure of SAS was used without the REPEATED statement. The Kenward-Roger method was used to calculate the approximate denominator degrees of freedom for the $F$ tests in the statistical models. Continuous data were tested for the distribution of 
the residuals after fitting the statistical models using Shapiro-Wilk and homogeneity of variance by plotting residuals against predicted values. Non-normally distributed data were subjected to Box-Cox transfor- mation using the TRANS-REG procedure of SAS to achieve normality before analyses. The least squares means were back-transformed and standard errors of the mean were calculated as outlined by Jørgensen and

Table 3. Reasons for removal of cows from the experiment $(n=16)$ and incidence of diseases in the early postpartum period in multiparous Holstein cows $(\mathrm{n}=93)$ fed prepartum diets formulated for caloric intake that greatly exceeded (EXE) or met requirement (MNE) of net energy and supplemented with $(+)$ or without (-) rumen-protected choline (RPC) during the perinatal period

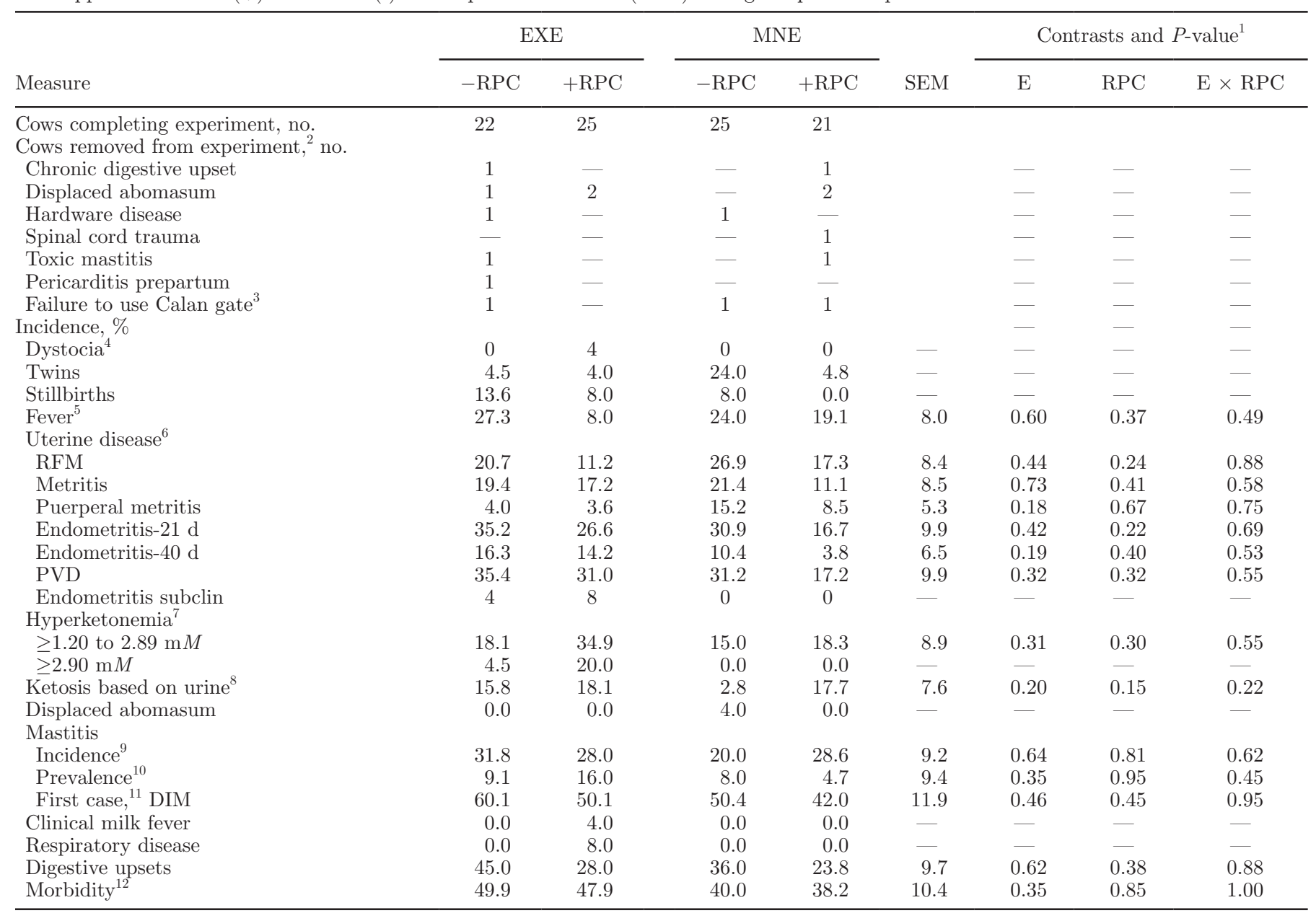

${ }^{1} \mathrm{E}=\mathrm{EXE}$ vs. MNE; $\mathrm{C}=-\mathrm{RPC}$ vs. $+\mathrm{RPC} ; \mathrm{E} \times \mathrm{RPC}=$ interaction.

${ }^{2}$ Failure to recover after prolonged treatment or from surgery.

${ }^{3}$ American Calan, Northwood, NH.

${ }^{4}$ Assisted calving if cows failed to progress toward delivery after 60 min from last observation.

${ }^{5}$ Rectal temperature $\geq 39.5^{\circ} \mathrm{C}$ in the first 12 DIM.

${ }^{6} \mathrm{RFM}$ (retained fetal membranes): retention $>24 \mathrm{~h}$ postcalving. Metritis: watery, fetid uterine discharge regardless of fever within 12 DIM. Puerperal metritis: metritis concurrent with fever within 12 DIM. Endometritis-21 and -40: vaginal discharge score of $>2$ using metricheck tool (Sheldon et al., 2006) at 21 and 40 DIM. Cows having vaginal discharge score $>2$ were classified as having purulent vaginal discharge (PVD). Endometritis subclin: subclinical endometritis diagnosed as stained cells in uterine flush being $>5 \%$ PMNL at $40 \pm 1$ DIM using the cytobrush technique.

${ }^{7}$ Plasma concentrations of BHB $>1.20 \mathrm{~m} M$ in the first 21 DIM were considered evidence of subclinical ketosis; plasma concentrations of BHB $\geq 2.90 \mathrm{~m} M$ were considered evidence of clinical ketosis.

${ }^{8}$ Urine having moderate $(\sim 40 \mathrm{mg} / \mathrm{dL})$ or large ketone concentrations $(>80 \mathrm{mg} / \mathrm{dL})$ and treated by veterinarians with oral propylene glycol or intravenous dextrose.

${ }^{9}$ (Number of diagnosed cows/number of cows per treatment $) \times 100 \%$.

${ }^{10}$ (Number of 5-d antibiotic treatments for mastitis/number of cows per treatment) $\times 100 \%$.

${ }^{11}$ Only cows diagnosed with mastitis were considered.

${ }^{12}$ Incidence of any clinical disease (retained fetal membranes, mastitis, metritis, ketosis, respiratory disease, digestive problems, or hypocalcemia). 
Pedersen (1998). Binary responses were analyzed by logistic regression using the GLIMMIX procedure of SAS. The model included the fixed effects of energy intake prepartum (EXE vs. MNE), RPC intake (with vs. without), and the interaction between energy intake prepartum and RPC intake. For repeated measurements within the same experimental unit, such as daily prevalence of $\mathrm{SCH}$, the model also included the fixed effects of time, interaction of treatment and time, and the random effect of cow nested within treatment. Time to event, such as interval to pregnancy by 210 DIM, was analyzed with Cox's proportional hazard regression model using the PHREG procedure of SAS using a model that included the effects of energy intake prepartum (MNE VS. EXE), RPC intake (with vs. without), and the interaction between energy intake prepartum and RPC intake. Statistical significance was considered at $P \leq 0.05$ and tendency was considered at $0.05<P \leq 0.10$.

\section{RESULTS AND DISCUSSION}

At $47 \pm 6$ d relative to expected calving date, cows assigned to the 4 dietary treatments did not differ in (mean $\pm \mathrm{SD})$ previous lactation number $(1.9 \pm 0.3)$, previous $305-\mathrm{d}$ mature-equivalent milk yield $(12,115 \pm$ $315 \mathrm{~kg})$, BCS $(3.55 \pm 0.07)$, or BW $(736 \pm 20 \mathrm{~kg})$. Sixteen of the 109 cows enrolled in the experiment were removed for the reasons provided in Table 3. The number of cows removed because of displaced abomasum or digestive problems that could be related to the energy density of the prepartum diets was similar $(\mathrm{n}=4$ and 3) for EXE and MNE treatments, respectively. By chance, 6 cows assigned to the MNE - RPC treatment delivered twins compared with 1 set of twins born to cows assigned to the other 3 treatments. None of the cows having twins experienced dystocia and completed the experiment. Diagnosis was more common for retained fetal membranes (5 of 9), clinical endometritis at 21 DIM (6 of 9), metritis between 4 and 12 DIM (6 of 9), and strong ketosis (3 of 9) compared with cows giving birth to single calves. Nevertheless, the incidence of these health disorders did not differ among treatments and were numerically similar (Table 3). Many cows delivering single calves $(\mathrm{n}=13)$ were diagnosed with both metritis within the first 12 DIM and clinical endometritis at 21 DIM; all 22 of these cows were included in the final analyses.

Feeding different prepartum diets had no influence on any measure of morbidity postpartum. Although important, caution should be used when interpreting these health data, as animal numbers were few and thus power was low. Janovick et al. (2011) reported greater incidence of ketosis and displaced abomasum in cows $(\mathrm{n}=47)$ fed at 167 versus $112 \%$ of $\mathrm{NE}_{\mathrm{L}}$ requirement for the entire dry period. Cows in their experiment fed the high-energy diet prepartum produced 5.6 $\mathrm{kg} / \mathrm{d}$ more milk but only consumed $0.6 \mathrm{~kg} / \mathrm{d}$ more DM compared with cows fed to maintenance during wk 2 to 3 of lactation, thus incidence of ketosis would likely increase. Mann et al. (2015) also reported fewer cases of postpartum hyperketonemia (BHB $\geq 1.2 \mathrm{mM}$ ) for prepartum cows fed 112 compared with cows fed 126 and $152 \%$ of $\mathrm{NE}_{\mathrm{L}}$ requirement.

Interactions between prepartum dietary energy intake and RPC supplementation were detected rarely; thus, our hypothesis was rejected. Therefore, results are presented and discussed under the heading of each main treatment separately.

\section{Prepartum Energy Intake (EXE vs. MNE)}

During the far-off period, mean intakes of DM and $\mathrm{NE}_{\mathrm{L}}$ were 12.9 versus $10.9 \mathrm{~kg} / \mathrm{d}$ and 21.0 versus 15.5 Mcal of $\mathrm{NE}_{\mathrm{L}} / \mathrm{d}$ for the EXE and MNE treatments, respectively. Individual cow DMI could not be analyzed during this period because cows were group-housed according to energy diet.

Parturition occurred earlier than expected on the basis of expected calving date, so only the last $15 \mathrm{~d}$ of gestation were used to analyze and report DMI prepartum. Mean DMI $(\mathrm{kg} / \mathrm{d}$ or $\%$ of BW) did not differ because of the energy density of the prepartum diets (Table 4). Likewise, in a review article by Grummer et al. (2004), DMI was similar in cows fed diets averaging 42 and $54 \%$ NDF, averaging 1.68 and $1.64 \%$ of BW, respectively. Diets in the current experiment had similar NDF content to the values reported by Grummer et al. (2004), 43 and 56\% NDF (Table 2), but DMI was less than they reported, averaging $1.52 \%$ of BW. This likely occurred because DMI was measured during the last 15 $\mathrm{d}$ of gestation and not $21 \mathrm{~d}$ as reported by Grummer et al. (2004). Although mean DMI was not affected, caloric intake differed as planned. Inclusion of straw at $37.5 \%$ of dietary DM successfully restricted consumption of calories during the dry period compared with cows fed the EXE diet. As a result of greater caloric intake, mean daily EB was greater $(P<0.01)$ by cows fed EXE compared with those fed MNE diets (1.24 vs. $1.00 \%$ of daily $\mathrm{NE}_{\mathrm{L}}$ requirement; Table 4). During the last $15 \mathrm{~d}$ of gestation, intake of $\mathrm{NE}_{\mathrm{L}}$ by cows fed EXE decreased from 140 to $102 \%$ of $\mathrm{NE}_{\mathrm{L}}$ requirement, whereas that of cows fed MNE decreased from 109 to $90 \%$ of $\mathrm{NE}_{\mathrm{L}}$ requirement (energy by time interaction, $P<0.01$; Figure 1). On average, cows fed MNE were in negative EB the last $6 \mathrm{~d}$ of gestation (means of -0.6 and -1.7 $\mathrm{Mcal} / \mathrm{d}$ for d 6 to 4 and 3 to 1, respectively). The DMI $(\mathrm{kg} / \mathrm{d}$ and as \% of BW) followed the same response as 


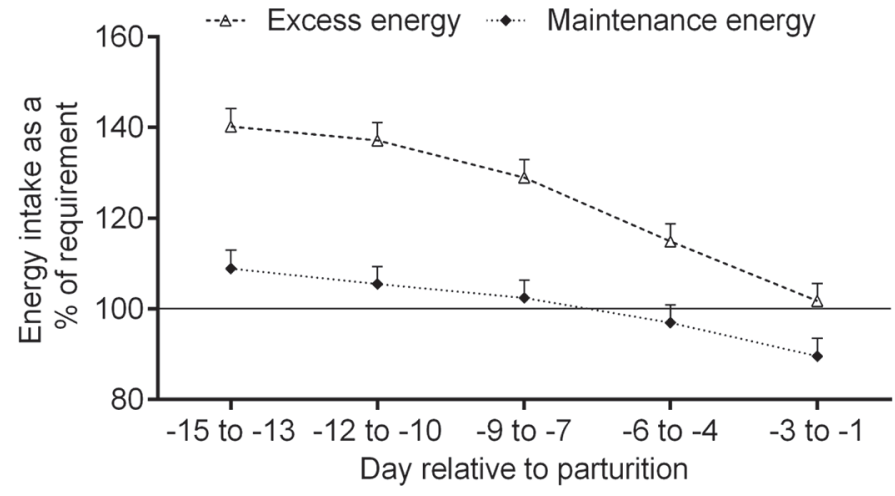

Figure 1. Effect of prepartum dietary energy density [maintenance or excess (1.40 or $1.63 \mathrm{Mcal}$ of $\mathrm{NE}_{\mathrm{L}} / \mathrm{kg}$ of feed $\left.\mathrm{DM}\right)$ ] on daily caloric intake expressed as a percentage of $\mathrm{NE}_{\mathrm{L}}$ requirement $(\mathrm{NRC}, 2001)$. Effects of dietary energy $(P<0.01)$ and dietary energy $\times$ time interaction were detected $(P<0.01)$. Error bars represent SEM.

$\mathrm{NE}_{\mathrm{L}}$ intake (energy by time interaction, $P<0.05$; Table 4). Cows of both treatments consumed DM at $1.3 \%$ of BW at calving, which agrees with the review article of Grummer et al. (2004). The rate of decrease in DMI was 0.28 compared with $0.15 \mathrm{~kg} / \mathrm{d}$ during the last $15 \mathrm{~d}$ of gestation for cows fed EXE and MNE, respectively. Likewise, the rate of decrease in DMI in the last days of gestation was greater in multiparous Holstein cows consuming excess calories throughout the dry period (Winkelman et al., 2008; Janovick and Drackley, 2010) compared with cows fed to maintenance. A more rapid decrease in DMI with approaching parturition has been associated with greater hepatic concentration of TAG at 1 DIM (Grummer et al., 2004).

Concentrations of some blood metabolites were influenced by caloric density of prepartum diet. Compared with cows fed MNE, cows fed EXE tended $(P$ $=0.07)$ to have lower mean concentrations of plasma fatty acids (252 vs. $296 \mu M)$ and had greater mean concentrations of plasma glucose ( $66.3 \mathrm{vs} .63 .5 \mathrm{mg} / \mathrm{dL}$ ) and insulin (0.42 vs. $0.33 \mathrm{ng} / \mathrm{mL}$; Table 4) during the prepartum period. Mean plasma concentrations of BHB prepartum were unaffected by treatments. Janovick et al. (2011) reported the same effects of prepartum feeding of high energy-dense diets on plasma concentrations of these metabolites and insulin when cows were fed excess rather than maintenance amounts of energy for the entire dry period. Mean concentration of plasma urea $\mathrm{N}$ prepartum also was lower in cows fed excess calories (7.7 vs. $9.0 \mathrm{mg} / \mathrm{dL}$ ), which is in agreement with Graugnard et al. (2012). This response pattern of plasma compounds fits with a scenario of differential intake of calories. Ruminal bacteria of cows consuming greater amounts of fermentable OM (i.e., EXE) would produce more propionate, a gluconeogenic precursor for the liver, resulting in greater circulating concentrations

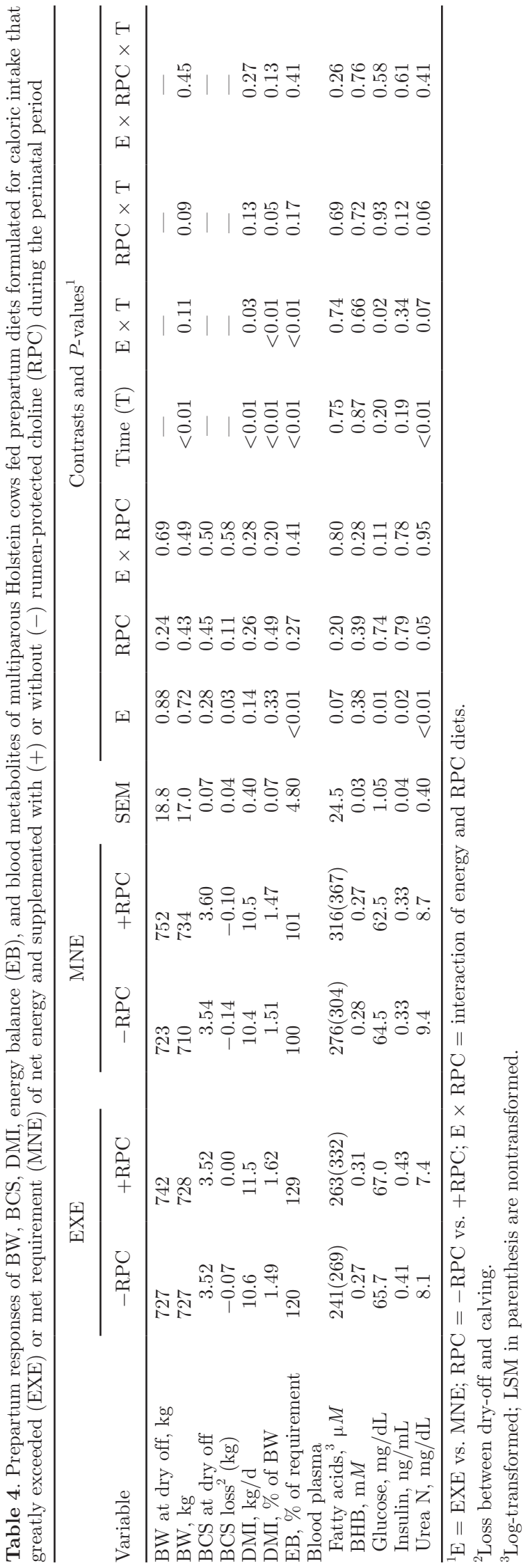


of glucose and insulin. Cows consuming more energy would rely less on body reserves for energy (fewer fatty acids mobilized from adipose tissue). As supporting evidence, in vitro lipolytic rates by adipose tissue were lower from overfed versus restricted-fed dairy cows 1 wk before calving (Rukkwamsuk et al., 1998). Reduced concentrations of circulating urea $\mathrm{N}$ in plasma could have resulted from more efficient use of dietary $\mathrm{N}$ by ruminal microbes given an increased supply of fermentable OM, resulting in less conversion of ammonia to urea by the liver despite greater intake of CP (Table 2).

Cows were dried off at a mean BW of 734 and 737 $\mathrm{kg}$ and a mean BCS of 3.52 and 3.57 for EXE and MNE diets, respectively (Table 4). Body weight was not measured just before calving, so changes in BW during the dry period were not calculated. Cows lost approximately 0.08 units of BCS during the 7 -wk nonlactating period (time, $P<0.01$, Table 4 ), which agrees with the 0.1 to $0.2 \mathrm{BCS}$ units lost during the dry period by cows fed 2 diets of similar energy density as the current experiment (Graugnard et al., 2013). Loss of body condition was slightly less $(P=0.03)$ for cows fed EXE compared with MNE ( -0.03 vs. -0.12 BCS; Table 4). Others reported that BCS was unaffected by the amount of calories consumed by pregnant cows for 6 to $7 \mathrm{wk}$ in the dry period (Grum et al., 1996; Winkelman et al., 2008). Drackley et al. (2014) failed to detected differences in BCS or carcass weight between nonlactating, nonpregnant cows consuming 15.3 vs. 25.8 Mcal of $\mathrm{NE}_{\mathrm{L}}$ per day for $56 \mathrm{~d}$ before slaughter. Nevertheless, amounts of omental, mesenteric, and perirenal adipose tissues, all part of the visceral fat, were greater ( 57.2 vs. $31.8 \mathrm{~kg}$ ) in cows consuming the most megacalories, an additional accumulation of 25.4 $\mathrm{kg}$ of fat that may negatively influence postpartum performance. It is important to mention that responses in BW and BCS to dietary energy density have been variable. Others reported gains of BW and BCS during the dry period when pregnant cows were consuming diets with increased energy density that result in caloric intakes much above requirements (Boisclair et al., 1986; Janovick and Drackley, 2010). Differences in BW and BCS reported among experiments may have resulted from differing amounts of physical activities by the nonlactating cows. Cows enrolled in the experiments of Boisclair et al. (1986) and Janovick and Drackley (2010) were housed in tiestalls, whereas cows in the current study were kept on outside dirt lots provided with shade structures.

After calving, mean DMI was lower $(P<0.01)$ for cows fed EXE than cows fed MNE diets (22.9 vs. 24.1 $\mathrm{kg} / \mathrm{d}$ and 3.49 vs. $3.71 \%$ of BW; Table 5 ). Intake of $\mathrm{DM}$ as a percent of BW was lower or tended to be lower by cows fed EXE from 2 to 14 wk postpartum (dietary energy by time interaction, $P<0.01$; Figure $2 \mathrm{~A})$. Previous research failed to detect changes in DMI postpartum by feeding ad libitum amounts of higher versus lower energy-dense diets using high-fiber forages during the entire dry period (Janovick and Drackley, 2010; Mann et al., 2015) or for the last 21 to $24 \mathrm{~d}$ of pregnancy (Ji et al., 2012; Zhang et al., 2015). However, Kunz et al. (1985) and Agenäs et al. (2003) reported a slower increase in DMI after calving when prepartum cows consumed calories in excess rather than in maintenance amounts. Greater postpartal DMI in cows fed MNE diets could have resulted from (1) greater distension, and thus a greater volume of the ruminal compartment by the increased prepartum consumption of wheat straw (a slowly degradable, high-NDF feed ingredient) that carried over to the postpartum period, because gut distention is a major controlling factor of intake immediately postpartum (Allen et al., 2009); (2) a less drastic shift in EB between the prepartum and postpartum periods for cows fed MNE prepartum, allowing a more rapid and capable response by homeorhetic mechanisms postpartum; and (3) a lower circulating concentration of insulin pre- and postpartum.

Mean yields of milk, 3.5\% FCM, and ECM did not differ between EXE and MNE treatment groups through 15 (Table 5; Figure 3A) and $40 \mathrm{wk}$ of lactation (Table 5 and Figure $4 \mathrm{~A}$ ). Production of $3.5 \%$ FCM and ECM were not different during the first 2 wk of lactation, but cows fed MNE appeared to consistently produce more milk from 5 to 15 wk postpartum (energy by time interaction, $P=0.01$; Figure 3A). Mean conversion of DMI to yields of ECM and 3.5\% FCM ranged from 1.84 to $1.97 \mathrm{~kg} / \mathrm{kg}$ across diets (Table 5). Efficiencies of conversion of DMI to ECM and FCM were greater during the first 4 wk postpartum by cows fed EXE (energy by time interaction, $P<0.01$; Figure 5A), likely due to lower DMI and use of adipose and muscle to support milk production. Regardless of whether prepartum intake of calories during the entire dry period was reduced through feed restriction (Kunz et al., 1985; Boisclair et al., 1986; Rukkwamsuk et al., 1998; Winkelman et al., 2008) or by ad libitum feeding of high-NDF diets (Graugnard et al., 2013; Mann et al., 2015), production of milk was not different compared with cows grossly overfed calories. Mean values for milk fat, true protein, SCC, and lactose $(\mathrm{kg} / \mathrm{d}$ or \%) were not affected by energy density of the prepartum diet (Table 5).

Mean EB after calving was more $(P=0.03)$ negative for cows fed $\operatorname{EXE}(-1.6$ vs. $-0.1 \mathrm{Mcal} / \mathrm{d}$; Table $5)$. The difference in EB between the 2 dietary energy treatment groups occurred primarily during the first 5 wk postpartum, with a tendency for a more negative EB detected at 10 and 12 wk postpartum for cows fed EXE compared with those fed MNE (energy by week 
ZENOBI ET AL.

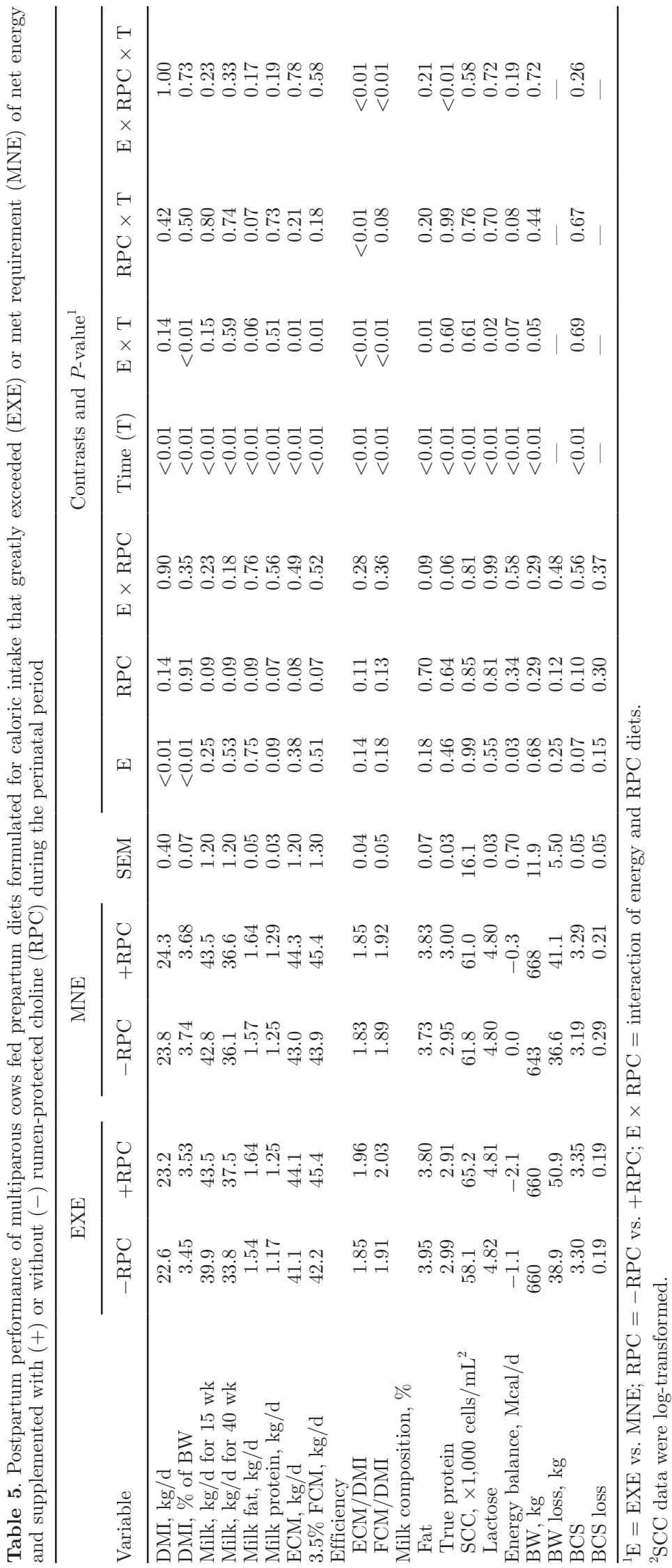


interaction, $P=0.07$; Figure $6 \mathrm{~A})$. Both treatments reached positive EB by 8 wk postpartum. In agreement, mean negative EB over the first 41 DIM postpartum was greater for cows fed an excess rather than a maintenance amount of calories prepartum (Graugnard et al., 2013). In addition, multiparous cows overconsuming calories prepartum took longer to reach positive EB after calving compared with those fed to maintenance in their prepartum period [due to a slower increase in DMI after calving (Agenäs et al., 2003) or due to a tendency for greater yield of 3.5\% FCM (Janovick and Drackley, 2010)].

Mean BCS tended $(P=0.07)$ to be slightly greater for EXE than MNE (3.32 vs. 3.24; Table 5); however, prepartum dietary energy did not affect loss of BW from calving to EB nadir at 4 wk postpartum (Figure 7A). Nevertheless, cows fed MNE steadily gained 31 $\mathrm{kg}$ between 5 and 15 wk postpartum, whereas cows fed EXE only gained $8 \mathrm{~kg}$ (energy by time interaction, $P$
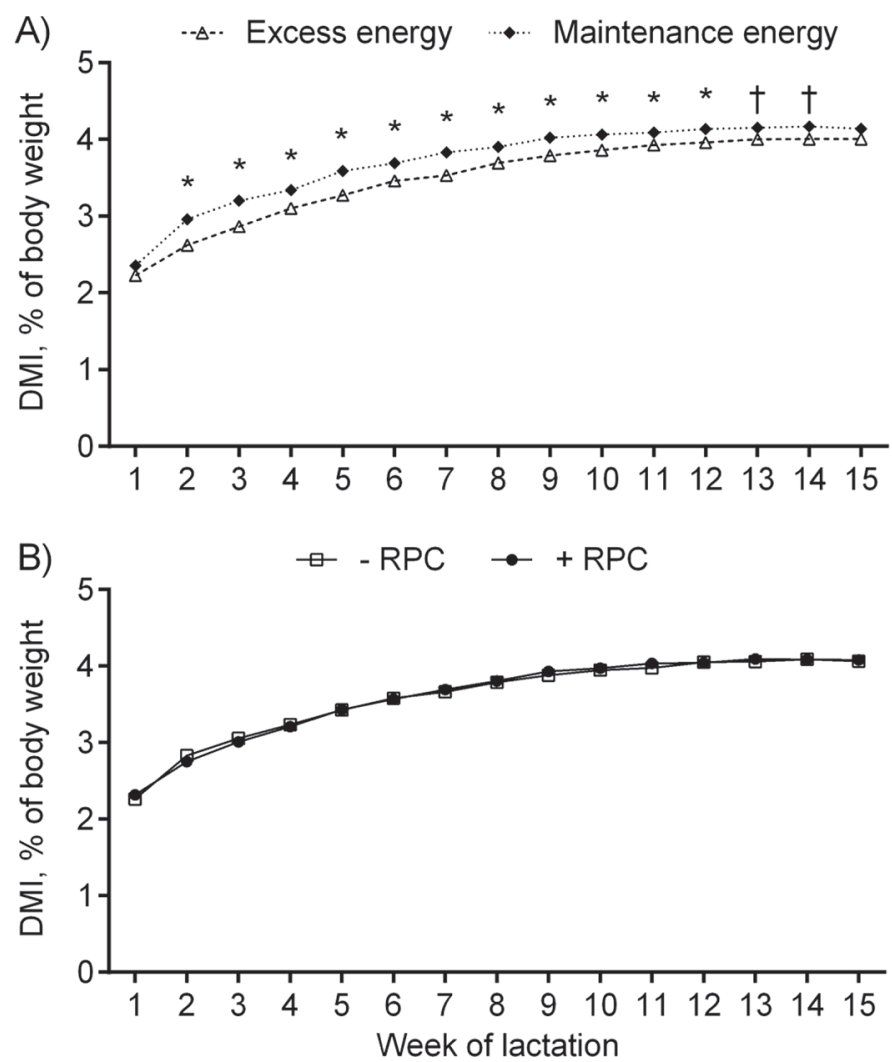

Figure 2. (A) Effect of prepartum dietary energy density [maintenance or excess (1.40 or $1.63 \mathrm{Mcal}$ of $\mathrm{NE}_{\mathrm{L}} / \mathrm{kg}$ of feed DM)] on postpartum DMI. Effects of dietary energy $(P<0.01)$ and dietary energy $\times$ time interaction $(P<0.01)$ were detected. (B) Effect of periparturient supplementation with or without ruminally protected choline $(+\mathrm{RPC}$ or $-\mathrm{RPC}$, respectively) on postpartum DMI. Effects of RPC $(P=$ $0.91)$ or $\mathrm{RPC} \times$ time interaction $(P=0.50)$ were not detected. At each week of lactation, differences between dietary treatments were found: ${ }^{*} P \leq 0.05, \dagger 0.05>P \leq 0.10$. Error bars represent SEM.

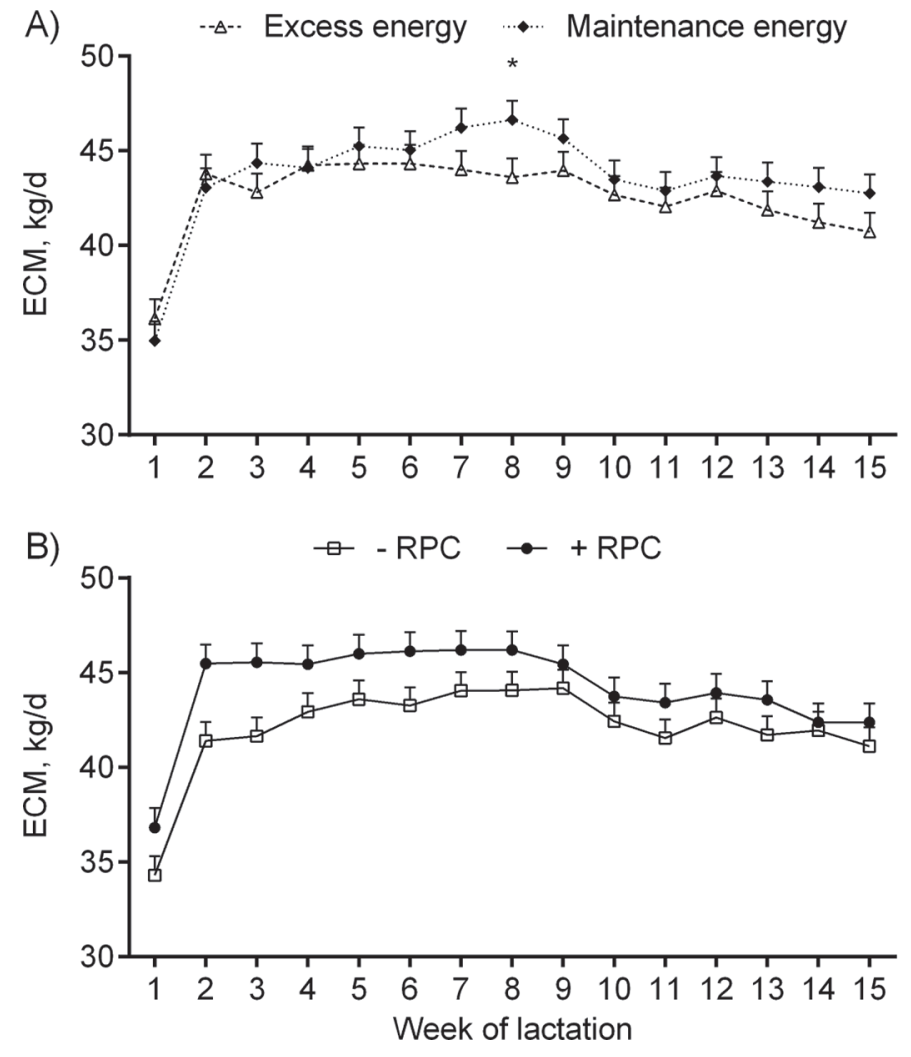

Figure 3. (A) Effect of prepartum dietary energy density [maintenance or excess (1.40 or 1.63 Mcal of $\mathrm{NE}_{\mathrm{L}} / \mathrm{kg}$ of feed $\left.\mathrm{DM}\right)$ ] on production of ECM for first 15 wk postpartum. Effects of dietary energy $(P=$ $0.38)$ and dietary energy $\times$ time interaction were detected $(P<0.01)$. (B) Effect of periparturient supplementation with or without ruminally protected choline ( $+\mathrm{RPC}$ or $-\mathrm{RPC}$, respectively) on production of ECM for first 15 wk postpartum. Effect of RPC was detected $(P=$ $0.08)$, whereas effect of RPC $\times$ time interaction was not detected $(P$ $=0.21$ ). At each week of lactation, differences between dietary treatments were found: ${ }^{*} P \leq 0.05$. Error bars represent SEM.

$=0.05 ;$ Figure $7 \mathrm{~A})$. The increased BW gain after 5 wk postpartum was caused primarily by increasingly greater consumption of calories beyond that needed for maintenance and milk production during a time when yield of ECM was decreasing in cows fed MNE compared with those fed EXE. Although the negative effect of overconsumption of calories prepartum on postpartum BW change has not been reported consistently, it has occurred when cows were overfed calories for the last 3 wk of pregnancy (Zhang et al., 2015) or for most of the dry period (Kunz et al., 1985; Rukkwamsuk et al., 1998; Agenäs et al., 2003).

As stated previously, cows fed EXE were in more negative EB during the first 5 wk postpartum, which resulted in marked differences in concentrations of metabolites in plasma. Feeding EXE tended $(P=0.10)$ to increase the mean concentration of plasma fatty acids $(502$ vs. $453 \mu M)$ postpartum (Table 6 ). Mean concentrations of fatty acids were 742 and $697 \mu M$ on the day 
of calving for cows fed EXE and MNE, respectively, but quickly decreased to around $550 \mu M$ by 7 DIM in both treatments. Increased plasma concentrations of fatty acids postpartum have resulted from dramatically overfeeding calories prepartum during most of the dry period (Kunz et al., 1985; Rukkwamsuk et al., 1998; Holtenius et al., 2003; Janovick et al., 2011; Graugnard et al., 2013; Mann et al., 2015) or during the last 3 wk of gestation (Ji et al., 2012; Zhang et al., 2015). Mean concentration of plasma BHB was greater across weeks ( 7.4 vs. $5.5 \mathrm{mM}$ ) for cows fed EXE compared with those fed MNE, but only differences at wk 1 and 3 postpartum were identified as significant (energy by time interaction, $P=0.01$; Table 6 ; Figure $8 \mathrm{~A}$ ). Mean concentrations of BHB peaked at 7 DIM at $1.0 \mathrm{~m} M$ for cows fed EXE (Figure 8A), but few cows were above the $1.2 \mathrm{mM}$ value proposed by McArt et al. (2012) as evidence of subclinical ketosis. Janovick et al. (2011), Ji et al. (2012), and Mann et al. (2015) reported this same positive relationship of prepartum caloric intake and postpartum circulating $\mathrm{BHB}$ response. Plasma concentrations of fatty acids and BHB typically increase as cows experience a greater negative EB (as did the cows fed EXE) due to the mobilization of fat from adipose and the production of ketones by the liver via incomplete oxidation of fatty acids. Circulating concentrations of glucose were unaffected (64.2 vs. $63.7 \mathrm{mg} / \mathrm{dL})$, although those of insulin tended $(P=$ $0.10)$ to be increased postpartum (0.17 vs. $0.13 \mathrm{ng} /$ $\mathrm{mL}$ ) in cows fed EXE compared with those fed MNE (Table 6). Likewise, greater insulin concentrations were reported for postpartal cows if greatly overfed calories prepartum (Kunz et al., 1985; Grum et al., 1996; Holcomb et al., 2001; Graugnard et al., 2013; Zhang et al.,
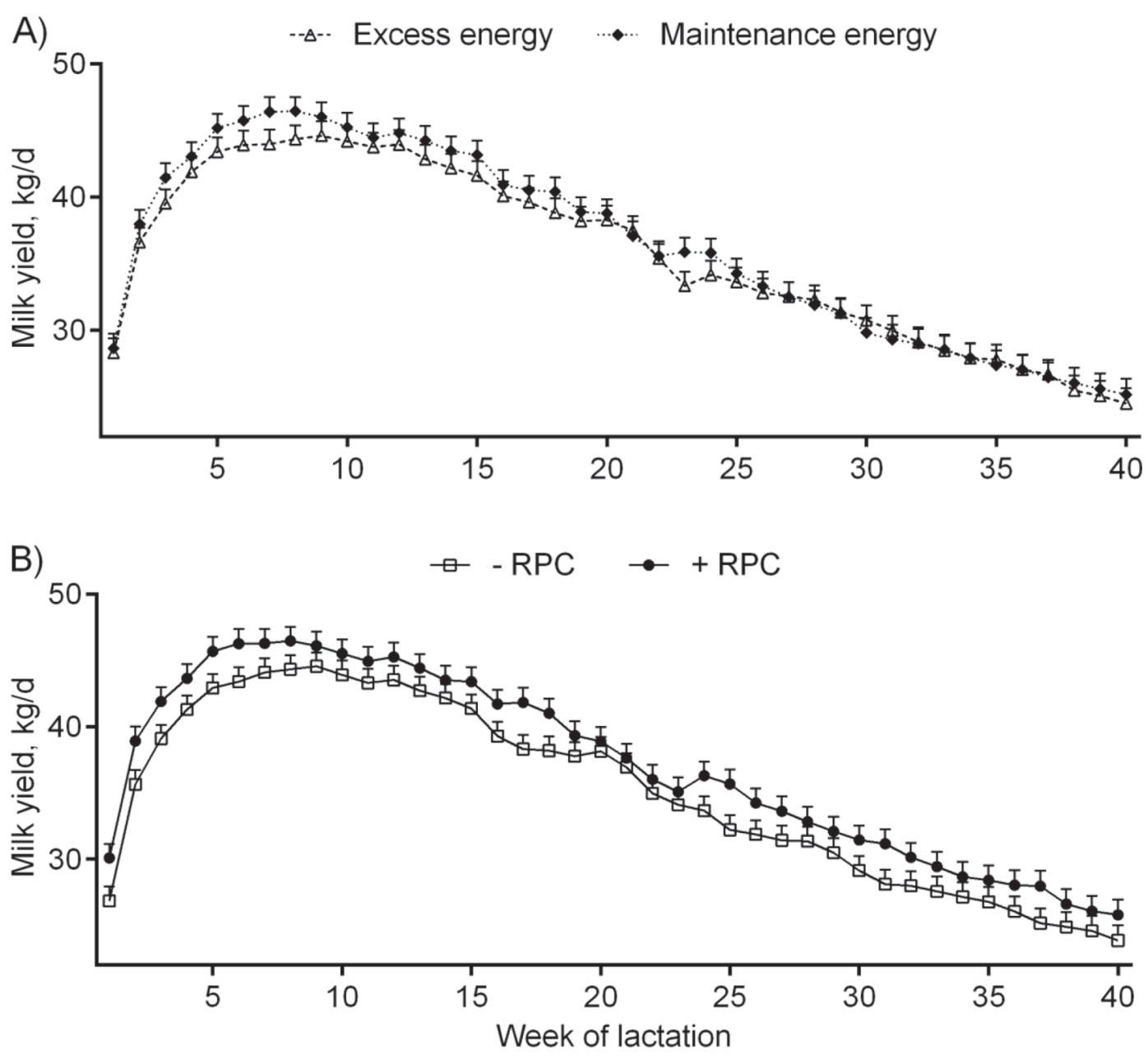

Figure 4. (A) Effect of prepartum dietary energy density [maintenance or excess (1.40 or $1.63 \mathrm{Mcal}$ of $\mathrm{NE} / \mathrm{kg}$ of feed DM)] on milk production for first $40 \mathrm{wk}$ postpartum. Effects of dietary energy $(P=0.53)$ or dietary energy $\times$ time interaction $(P=0.59)$ were not detected. $(\mathrm{B})$ Effect of periparturient supplementation with or without ruminally protected choline ( $+\mathrm{RPC}$ or $-\mathrm{RPC}$, respectively) on milk production for first 40 wk postpartum. Effect of RPC was detected $(P=0.09)$ whereas effect of RPC $\times$ time interaction was not detected $(P=0.74)$. Error bars represent SEM. 
2015). Offering diets that excessively exceeded rather than slightly exceeded energy requirements prepartum stimulated insulin release starting in the prepartum period and carried over to the postpartum period in the current study. The elevated insulin concentrations of postpartal cows fed EXE was surprising, because cows fed EXE were in a greater negative EB than cows fed MNE for the first 5 wk postpartum. This increased insulin could mediate an increase in circulating concentrations of leptin from adipose tissue (Asakuma et al., 2003), a hormone known to depress feed intake via the hypothalamus (Houseknecht et al., 1998). In addition, prepartum concentrations of plasma leptin tended to be greater in cows fed excess rather than restricted amounts of calories prepartum (Holtenius et al., 2003). Thus, postpartum DMI may have been lower in cows fed EXE prepartum because of the greater presence of
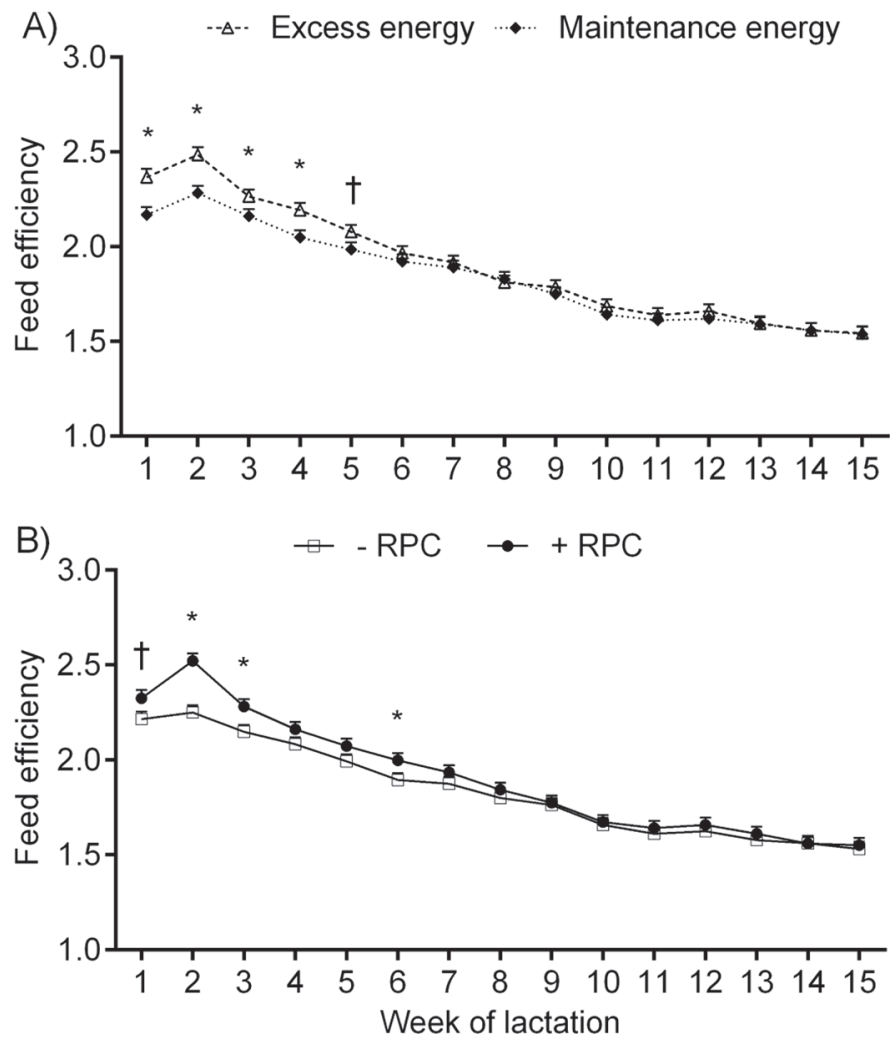

Figure 5. (A) Effect of prepartum dietary energy density density [maintenance or excess $\left(1.40\right.$ or $1.63 \mathrm{Mcal}$ of $\mathrm{NE}_{\mathrm{L}} / \mathrm{kg}$ of feed $\left.\mathrm{DM}\right)$ ] on efficiency of converting feed DM into ECM. Effect of dietary energy $(P$ $=0.14)$ was not detected but effect of dietary energy $\times$ time interaction was detected $(P<0.01)$. (B) Effect of periparturient supplementation with or without ruminally protected choline $(+\mathrm{RPC}$ or $-\mathrm{RPC}$, respectively) on efficiency of converting feed DM into ECM. Effect of RPC was not detected $(P=0.11)$, but effect of RPC $\times$ time interaction was detected $(P<0.01)$. At each week of lactation, differences between dietary treatments were found: ${ }^{*} P \leq 0.05, \dagger 0.05>P \leq 0.10$. Error bars represent SEM. leptin starting prepartum and the stimulating influence of insulin on leptin release from adipose postpartum.

Dietary energy density prepartum did not affect concentrations of hepatic TAG at 2 wk prepartum, which averaged 2.3 and $2.7 \%$ of liver DM in cows fed EXE or MNE, respectively (Figure 9A). However, mean concentration of TAG from 3 weekly biopsies starting at 7 DIM was greater in liver of cows fed EXE compared with those fed MNE (10.6 vs. $8.5 \% P=0.04 ; 7.3$ vs. 5.2 $\mu \mathrm{g} / \mu \mathrm{g}$ of DNA, $P<0.01$; Table 6$)$, with the values at 7 (11.1 vs. $8.7 \%$ of DM) and 21 DIM (10.1 vs. $7.6 \%$ of $\mathrm{DM}$ ) detected as different (energy by time interaction, $P=0.10$; Figure 9A), matching the effect of prepartum energy intake on concentration of plasma BHB. In their review article, Bobe et al. (2004) reported that plasma concentrations of BHB and fatty acids were positively and strongly associated with fatty liver, metabolites that are elevated as cows experience greater negative EB. Increases in plasma BHB, fatty acids, and nega-
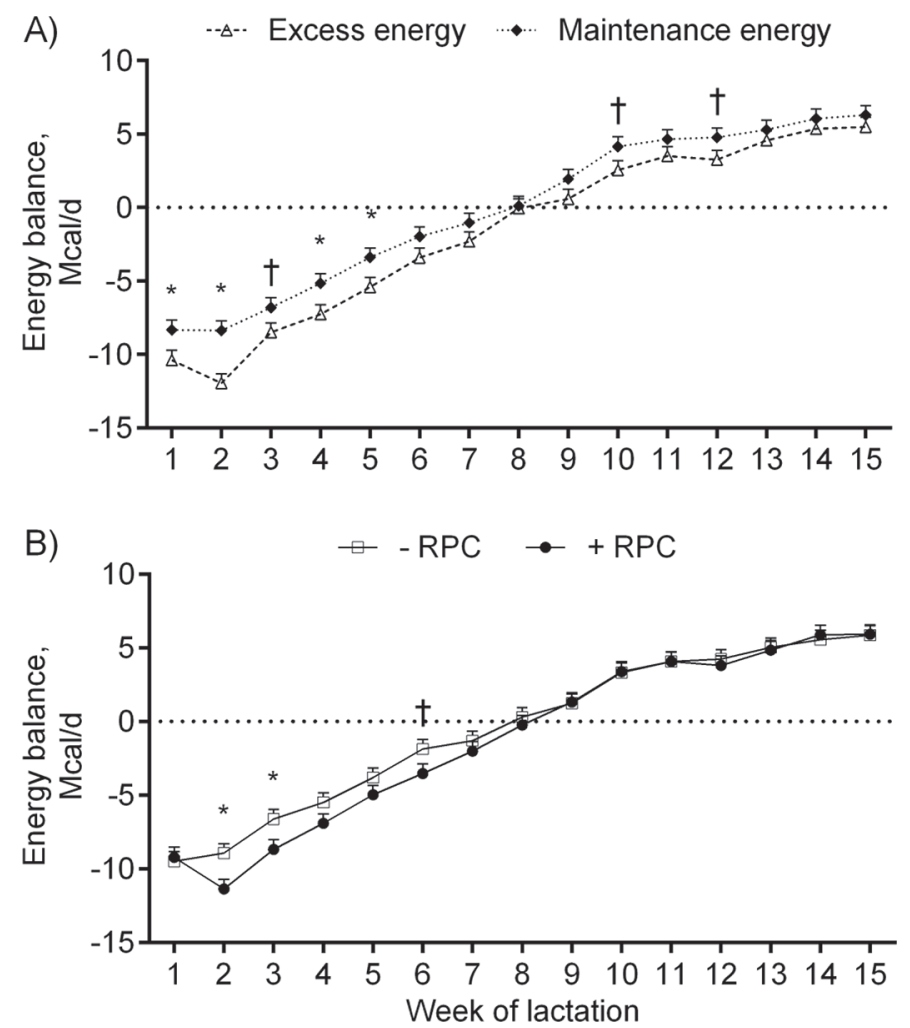

Figure 6. (A) Effect of prepartum dietary energy density [maintenance or excess (1.40 or $1.63 \mathrm{Mcal}$ of $\mathrm{NE}_{\mathrm{L}} / \mathrm{kg}$ of feed $\left.\mathrm{DM}\right)$ ] on postpartum energy balance. Effects of dietary energy $(P=0.03)$ and dietary energy $\times$ time interaction were detected $(P=0.07)$. (B) Effect of periparturient supplementation with or without ruminally protected choline ( $+\mathrm{RPC}$ or $-\mathrm{RPC}$, respectively) on postpartum energy balance. Effect of RPC was not detected $(P=0.34)$, but effect of RPC $\times$ time interaction was detected $(P=0.08)$. At each week of lactation, differences between dietary treatments were found: ${ }^{*} P \leq 0.05, \dagger 0.05>P \leq$ 0.10. Error bars represent SEM. 

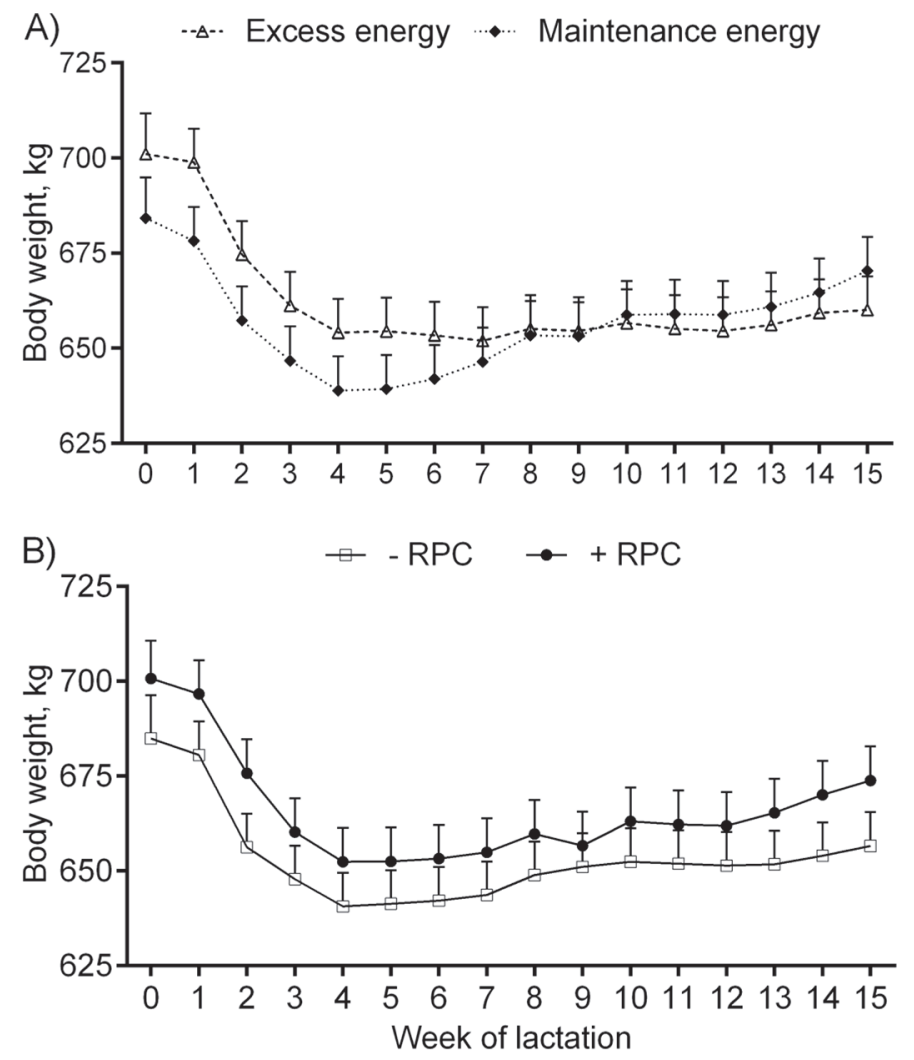

Figure 7. (A) Effect of prepartum dietary energy density [maintenance or excess (1.40 or $1.63 \mathrm{Mcal}$ of $\mathrm{NE}_{\mathrm{L}} / \mathrm{kg}$ of feed $\left.\mathrm{DM}\right)$ ] on postpartum BW. Effect of dietary energy was not detected $(P=0.68)$ but effect of dietary energy $\times$ time interaction was detected $(P=$ 0.05). (B) Effect of periparturient supplementation with or without ruminally protected choline ( $+\mathrm{RPC}$ or $-\mathrm{RPC}$, respectively) on postpartum BW. Effects of RPC $(P=0.29)$ and $\mathrm{RPC} \times$ time interaction $(P=0.44)$ were not detected. At each week of lactation, differences between dietary treatments were found: $\dagger 0.05>P \leq 0.10$. Error bars represent SEM.

tive EB are in agreement with the greater hepatic TAG detected for cows fed EXE prepartum. Incidence of hepatic lipidosis based on TAG $>5 \%$ of wet tissue (Gaal et al., 1983) tended to be greater $(P=0.07)$ in cows overfed energy prepartum (22.6 vs. $8.1 \%$ for EXE and MNE, respectively). Excessive feeding of calories for most of the dry period resulted in greater concentrations of hepatic TAG at 1, 14, and 21 DIM (Janovick et al., 2011). Andersen et al. (2002) reported that insulin suppressed $\beta$-oxidation of long-chain fatty acids by the liver of lactating dairy cows. A similar action by elevated plasma insulin in the current experiment, along with the elevated plasma concentration of fatty acids in cows fed EXE, may have led to increased hepatic esterification of fatty acids and would help explain the increased concentrations of hepatic TAG. Activity of carnitine palmitoyltransferase was reduced at 1 DIM in hepatic mitochondria of multiparous cows fed excess compared with those fed moderate amounts of calories in the prepartum period (Douglas et al., 2006), which supports a reduced $\beta$-oxidation by hepatic tissue from overfed prepartum cows.

Mean concentration of tCa ( 8.5 vs. $8.7 \mathrm{mg} / 100 \mathrm{~mL})$ and prevalence of SCH (19.3 vs. 16.7\%) did not differ between EXE and MNE treatments, respectively (Table 6). Based upon ultrasonography, energy intake prepartum did not influence the proportion of cows cycling by $40 \pm 3$ DIM (78.7 vs. $82.5 \%$ ) for EXE and MNE treatments, respectively. Neither average days to pregnancy (138 vs. 134 DIM) nor pregnancy at first AI (32 vs. $32 \%$ for MNE vs. EXE groups, respectively) were affected by prepartum energy intake.

Yield of colostrum (8.9 vs. $9.2 \mathrm{~kg}$ ) and concentration of $\operatorname{IgG}(76.1$ vs. $78.9 \mathrm{~g} / \mathrm{L}$ ) were not affected by amount of energy consumed prepartum (EXE and MNE, respectively; Table 7). Recently, Mann et al. (2016) reported greater concentration of $\mathrm{IgG}$ in colostrum from multiparous cows fed at 112 versus $157 \%$ of $\mathrm{NE}_{\mathrm{L}}$ requirement during the prepartum period.

To examine the influence of in utero exposure to maternal intake of 2 amounts of energy, the growth of 35 heifers (18 from EXE dams and 17 from MNE dams) were followed for $1 \mathrm{yr}$. All heifers were managed the same with the exception that the source of colostrum fed was not controlled except that it exceeded $22 \%$ Brix. Body weights at birth, weaning, and at $50 \mathrm{wk}$ of age were not different due to dietary treatment, such that all measures of ADG were unaffected (Table 7).

\section{Choline Supplementation During the Periparturient Period}

The RPC was supplemented for $17 \pm 4.6 \mathrm{~d}$ prepartum through 21 DIM for a total period of approximately 38 d. All cows received RPC for a minimum of $7 \mathrm{~d}$ prepartum, with 42 cows (91.3\%) supplemented for a minimum of $11 \mathrm{~d}$ prepartum.

Incidence of the individual diseases and disorders listed in Table 3, as well as morbidity as a whole, were not affected by feeding RPC in our study of 93 cows. In a field experiment involving 357 primiparous and multiparous cows, incidence of clinical ketosis, in particular, and general morbidity (retained fetal membranes, metritis, clinical ketosis, displaced abomasum, and mastitis) were reduced ( 57.0 vs. $38.4 \%$ ) by feeding RPC from -25 to 80 DIM (Lima et al., 2012). In their second field experiment of 573 primiparous cows, feeding RPC only during the last $22 \mathrm{~d}$ of pregnancy resulted in reduced incidence of retained fetal membranes (6.7 vs. $2.1 \%$ ) and mastitis cases per cow (0.09 vs. 0.04$)$, but general morbidity tended to increase (33.7 vs. $41.2 \%$; Lima et al., 2012). Supplemental choline may need to be fed in the prepartum and postpartum periods when 
PREPARTUM ENERGY INTAKE AND CHOLINE

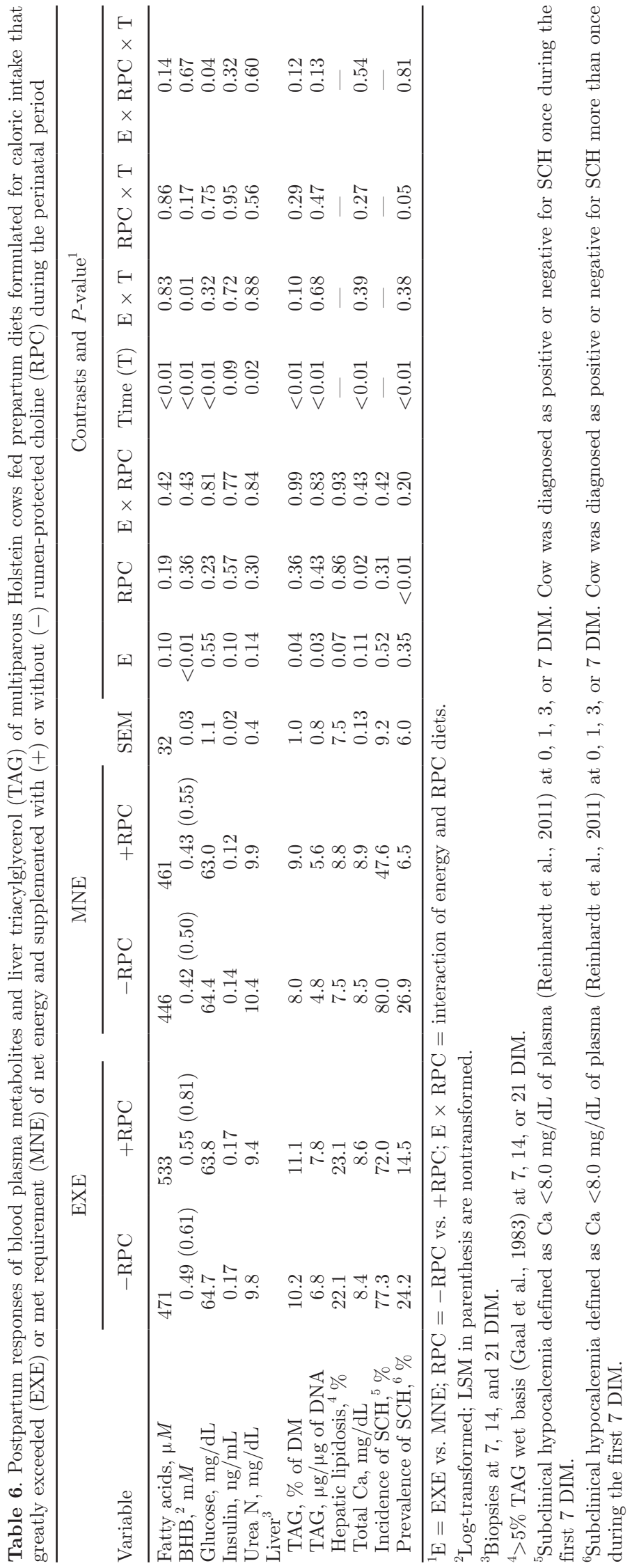



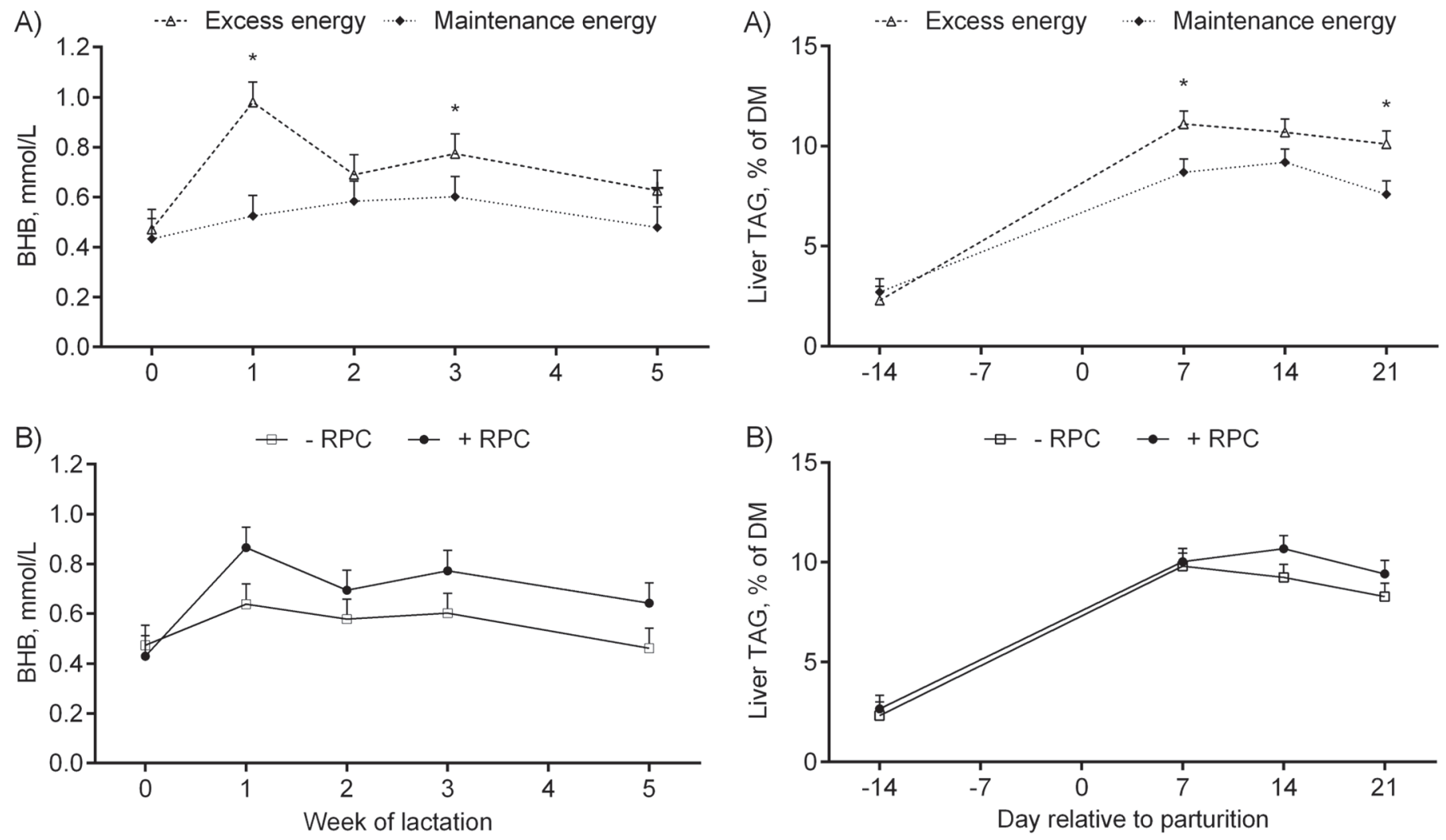

Figure 8. (A) Effect of prepartum dietary energy density [maintenance or excess (1.40 or $1.63 \mathrm{Mcal}$ of $\mathrm{NE}_{\mathrm{L}} / \mathrm{kg}$ of feed DM)] on postpartum concentrations of BHB. Effects of dietary energy $(P<0.01)$ and dietary energy $\times$ time interaction were detected $(P=0.01)$. (B) Effect of periparturient supplementation with or without ruminally protected choline ( $+\mathrm{RPC}$ or $-\mathrm{RPC}$, respectively) on postpartum concentrations of BHB. Effects of RPC $(P=0.36)$ and $\mathrm{RPC} \times$ time interaction $(P=$ 0.17 ) were not detected. At each week of lactation, differences between dietary treatments were found: $\dagger 0.05>P \leq 0.10$. Error bars represent SEM.

Figure 9. (A) Effect of prepartum dietary energy density [maintenance or excess (1.40 or $1.63 \mathrm{Mcal}$ of $\mathrm{NE}_{\mathrm{L}} / \mathrm{kg}$ of feed $\left.\mathrm{DM}\right)$ ] on concentration of liver triacylglycerol (TAG). Effects of dietary energy $(P=$ $0.04)$ and dietary energy $\times$ time interaction were detected $(P=0.10)$. (B) Effect of periparturient supplementation with or without ruminally protected choline $(+\mathrm{RPC}$ or $-\mathrm{RPC}$, respectively) on concentration of liver TAG. Effects of RPC $(P=0.36)$ and $\mathrm{RPC} \times$ time interaction $(P=0.39)$ were not detected. At each day relative to parturition, differences between dietary treatments were found: ${ }^{*} P \leq 0.05$. Error bars represent SEM.

Table 7. Yield and quality of colostrum and growth of heifers born to multiparous Holstein cows fed prepartum diets formulated for caloric intake that greatly exceeded (EXE) or met requirement (MNE) of net energy and supplemented with $(+)$ or without $(-)$ rumen-protected choline (RPC) during the perinatal period

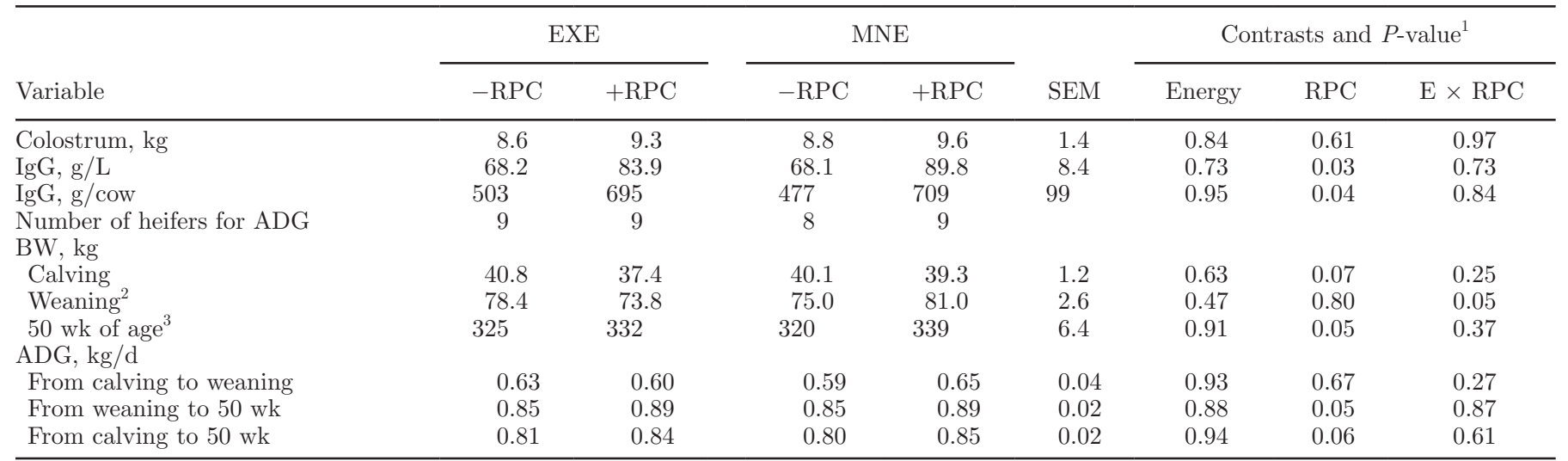

${ }^{1} \mathrm{E}=\mathrm{EXE}$ vs. $\mathrm{MNE} ; \mathrm{RPC}=-\mathrm{RPC}$ vs. $+\mathrm{RPC} ; \mathrm{E} \times \mathrm{RPC}=$ interaction of energy and $\mathrm{RPC}$ diets.

${ }^{2} 61.1 \pm 3.3 \mathrm{~d}$ of age.

${ }^{3} 350.0 \pm 2.2 \mathrm{~d}$ of age. 
$\mathrm{EB}$ is negative and the immune system is under the greatest stress to maximize potential health benefits.

Mean BW was 725 and $747 \mathrm{~kg}$ and mean BCS was 3.53 and 3.58 when dried off and assigned to the $-\mathrm{RPC}$ and $+\mathrm{RPC}$ treatments, respectively, and did not differ (Table 4). Mean DMI during the last $15 \mathrm{~d}$ of gestation did not differ (10.5 vs. $11.0 \mathrm{~kg} / \mathrm{d}$ and 1.50 vs. $1.54 \%$ of $\mathrm{BW}$ for the $-\mathrm{RPC}$ and $+\mathrm{RPC}$ groups, respectively; Table 4), nor did mean EB. Plasma concentrations of fatty acids, $\mathrm{BHB}$, glucose, and insulin were unaffected by RPC supplementation during the last $3 \mathrm{wk}$ of gestation (Table 4).

The mean DMI during the postpartum period ( $15 \mathrm{wk}$ ) averaged $23.2 \mathrm{~kg} / \mathrm{d}$ for $-\mathrm{RPC}$ and $23.8 \mathrm{~kg} / \mathrm{d}$ for $+\mathrm{RPC}$ groups and did not differ (Table 5; Figure 2A). Mean yields of milk ( 43.5 vs. $41.3 \mathrm{~kg} / \mathrm{d}$ ), ECM ( 44.2 vs. 42.0 $\mathrm{kg} / \mathrm{d}$ ), and $3.5 \%$ FCM (45.4 vs. $43.1 \mathrm{~kg} / \mathrm{d}$ ) tended to be greater $(P<0.10)$ for the + RPC compared with the RPC group (Table 5; Figure 3B). When milk yield was analyzed up to $40 \mathrm{wk}$, again the $+\mathrm{RPC}$ group tended to produce more milk ( 36.9 vs. $34.8 \mathrm{~kg} / \mathrm{d}, P=0.08$; Figure 4B), demonstrating a carry-over effect after the supplementation ended at 21 DIM due to greater peak yield of milk. Choline supplementation also tended to increase yields of milk fat $(P=0.09)$ and protein $(P=$ 0.07 ) due to increased milk yield. Mean concentration of fat and protein tended to decrease in the milk of cows fed EXE, but increased in the milk of cows fed MNE due to RPC supplementation $(P<0.10$, Table $5)$. Cows categorized as the bottom $50 \%$ in milk yield in the current experiment had a $1.1 \mathrm{~kg} / \mathrm{d}$ greater milk response to RPC than the top 50\%. Because RPC was fed at a constant amount of $60 \mathrm{~g} / \mathrm{d}$, the ratio of $\mathrm{RPC}$ intake per unit of milk production was greater for lower producers compared with that of the higher-producing cows. Hence, the amount of RPC fed in the current experiment may not have been sufficient to capture all of the benefit of RPC for higher-producing cows. If only cows with BCS of $\leq 3.50$ at calving were considered $(\mathrm{n}=76)$, milk response to RPC supplementation was $2.7 \mathrm{~kg} / \mathrm{d}(P=0.09)$, indicating that moderately conditioned cows responded well to RPC.

Others have reported that yield of milk or FCM increased or tended to increase when RPC was fed with methionine-adequate diets (Piepenbrink and Overton, 2003; Lima et al., 2012; Sun et al., 2016), although these groups fed RPC starting prepartum through 60 to 80 d postpartum; only Sun et al. (2016) fed RPC for 21 d postpartum, as was done in the current experiment. In addition, others fed diets considered inadequate in methionine and still reported greater milk yield due to supplementation with RPC (Pinotti et al., 2003; Zahra et al., 2006; Amrutkar et al., 2015). Some authors reported no change in milk yield with RPC supplementa- tion (Zom et al., 2011; Zhou et al., 2016); the milk yield response detected in the current trial $(2.2 \mathrm{~kg} / \mathrm{d})$ is comparable to the average of all those trials.

Although mean efficiency of production of ECM and FCM was unaffected $(P=0.11$ to 0.13 , Table 5$)$ by RPC, efficiency of ECM production was greater at wk $1,2,3$, and 6 when RPC was fed (RPC by time interaction, $P<0.01$; Table 5; Figure 5B). Likewise, mean EB did not differ due to RPC supplementation but EB was more negative at wk $2(-8.9$ vs. $-6.6 \mathrm{Mcal} / \mathrm{d})$ and $3(-11.4$ vs. $-8.7 \mathrm{Mcal} / \mathrm{d})$ and tended to be more negative at wk 6 postpartum for cows fed RPC (RPC by time interaction, $P=0.08$; Figure $6 \mathrm{~B}$ ). Both groups reached positive EB by wk 8 postpartum. The mean $\mathrm{BW}$ and BCS and the pattern of loss and gain of BW and body condition (Figure 7B) were not different between the 2 treatment groups. Therefore, the improved efficiency of milk production may have been due partially to improved utilization of feed nutrients. Totaltract digestibility of OM (including ether extract) was increased for lactating cows fed 15 or $30 \mathrm{~g} / \mathrm{d}$ of RPC compared with those not fed RPC chloride (Mohsen et al., 2011). Lactating rats fed diets deficient in choline had shorter villi in the jejunum and a reduced capacity to absorb fat compared with rats supplemented with choline or PC, possibly due to choline's role in chylomicron assembly (da Silva et al., 2015).

Despite the fact that cows fed RPC were in a more negative energy state during wk 2 and 3 postpartum (Figure 6B), supplementation of RPC had no effect on the mean concentrations of plasma fatty acids, BHB, glucose, insulin, and BUN (Table 6; Figure 8B). Literature reporting the effect of supplementing RPC on the concentration of these metabolites is equivocal. Postpartum plasma concentrations of glucose, fatty acids, and BHB did not differ between control and RPCsupplemented lactating cows (Janovick Guretzky et al., 2006; Zom et al., 2011), although others have reported decreased plasma concentrations of BHB (Elek et al., 2013; Sun et al., 2016) and fatty acids (Sun et al., 2016) but greater plasma concentrations of glucose (Sun et al., 2016) when RPC was supplemented.

Prepartum hepatic TAG values were 2.3 and $2.7 \%$ of DM and 1.50 and $1.58 \mu \mathrm{g} / \mu \mathrm{g}$ of DNA for cows not fed or fed RPC, respectively (Figure 9B). Just as RPC intake did not affect postpartum circulating concentrations of fatty acids and BHB, RPC did not influence mean concentrations of hepatic TAG postpartum (9.1 vs. $10.0 \%$ of $\mathrm{DM}$ and 5.8 vs. $6.7 \mu \mathrm{g} / \mu \mathrm{g}$ of DNA; Table 6). The pattern of changing hepatic TAG over the first 3 wk postpartum was not affected by RPC (Figure 9B). Likewise, prevalence of lipidosis was not different between $-\mathrm{RPC}$ and $+\mathrm{RPC}$ groups (13.2 vs $14.5 \%$, respectively). Lack of lipidosis in cows fed RPC 
was somewhat surprising because of the cow's greater negative EB during the first 2 to $3 \mathrm{wk}$ postpartum. The greater extent of negative $\mathrm{EB}$ during wk 2 to 3 postpartum of cows fed RPC, extending down to -11.5 $\mathrm{Mcal} / \mathrm{d}$, would suggest a likely increase in hepatic fat in the current experiment. It is possible that feeding RPC may have prevented greater accumulation of fat by the liver of cows in greater negative EB. When cows were split into 2 groups of most negative $\mathrm{EB}(\mathrm{n}=46)$ and least negative $\mathrm{EB}(\mathrm{n}=47)$ averaged across wk 2 and 3, RPC supplementation did not affect liver TAG concentration averaged across wk 2 and 3 in either group. Piepenbrink and Overton (2003) and Zahra et al. (2006) reported no effect of RPC on hepatic TAG, although the former reported increased concentrations of glycogen with increasing consumption of RPC. However, esterified products tended to decrease when liver slices from cows fed increasing amounts of RPC were incubated in vitro with carbon 14-labeled palmitic acid (Piepenbrink and Overton, 2003), indicating increasing production of lipoproteins such as very low density lipoproteins, which is necessary to export TAG from the liver. Alternatively, several studies have reported a reduction of TAG in liver of early-lactation multiparous cows fed RPC (Santos and Lima, 2009; Zom et al., 2011; Elek et al., 2013).

Our hypothesis was that supplemental RPC would have a more positive effect on cows prone to develop hepatic lipidosis; that is, cows fed the EXE diet prepartum. Indeed, cows fed EXE had greater hepatic TAG compared with those fed MNE (Table 6), but RPC supplementation did not preferentially reduce hepatic TAG in those cows fed EXE. A lack of consistency by supplemental RPC to reduce hepatic TAG across experiments may result from (1) differences in cholinestatus of cows across studies, (2) insufficiency of a 1.5-g sample of liver tissue collected via biopsy to consistently represent a 7 to $9 \mathrm{~kg}$ liver, and (3) a lack of sufficient hepatic lipidosis in control cows to allow a benefit from supplemental RPC. The mean concentration of hepatic TAG of control cows in the current study was 9.1\% (DM basis; Table 6) averaged across the first 21 DIM. This concentration converts to $2.3 \%$ (wet basis), assuming that liver is $25 \% \mathrm{DM}$. The hepatic concentration of TAG in control cows was 7.5 and $10 \%$ (wet tissue basis) in 2 experiments (Zom et al., 2011; Elek et al., 2013) that reported a reduction in hepatic TAG due to RPC supplementation, whereas concentrations were approximately 16 and $11.5 \%$ (wet basis, averaged between 1 and 21 DIM) in control cows that did not respond to supplemental RPC (Piepenbrink and Overton, 2003; Zahra et al., 2006). In these 4 studies, TAG concentration of control cows were relatively high (Bobe et al., 2004) and similar in value, and therefore would not account for lack of RPC effect. Control cows in the current study may not have accumulated enough TAG to allow RPC to provide a detectable benefit.

Consumption of RPC tended $(P=0.09)$ to increase milk by $2.2 \mathrm{~kg} / \mathrm{d}$ per cow despite no apparent improvement in liver function. This improvement may have been through a combination of improved DMI and energy mobilization. Cows fed RPC had numerically greater intake of feed DM $(0.6 \mathrm{~kg} / \mathrm{d})$, greater loss of BW (46.0 vs. $37.8 \mathrm{~kg}$ ), and a greater oxidation of fatty acids for energy in early lactation, thus sparing some glucose for increased synthesis of lactose for milk production. An increased efficiency or extent of fatty acid oxidation may result from choline's documented effects upon carnitine. Carnitine is required to transport longchain fatty acids into the mitochondria for $\beta$-oxidation of fatty acids. Choline is a methyl donor for the hepatic synthesis of carnitine (Bremer, 1983). Second, expression of mRNA of 2 key proteins (fatty acid transporter 5 and organic cation-carnitine transporter SLC22A5) for transporting carnitine into hepatocytes were increased in cows supplemented with RPC (Goselink et al., 2013). Increased dietary intake of carnitine by periparturient Holstein cows reduced concentration of TAG in liver by $>50 \%$ and increased in vitro production of glucose from alanine by liver tissue collected via biopsy (Carlson et al., 2007). Circulating concentrations of glucose have been increased in dairy cows fed RPC (Baldi and Pinotti, 2006; Soltan et al., 2012; Sun et al., 2016), but not in others (Zahra et al., 2006; Zom et al., 2011; Elek et al., 2013). If choline is increasing the synthesis of carnitine, which may allow more fatty acids to undergo oxidation, the plasma concentration of ketones may be reduced if their oxidation is completed. Only Elek et al. (2013) and Sun et al. (2016) reported lower concentration of plasma BHB in fresh cows fed RPC, whereas others reported no effect of RPC supplementation on circulating BHB (Piepenbrink and Overton, 2003; Zahra et al., 2006; Zom et al., 2011).

Cows supplemented with RPC had greater mean concentration of tCa in plasma in the first 7 DIM compared with cows that did not received RPC (8.7 vs. $8.4 \mathrm{mg} / \mathrm{dL}$, respectively, $P=0.02$; Table 6 ; Figure 10). Across treatments, $70 \%$ of all cows had tCa in plasma below $8 \mathrm{mg} / \mathrm{dL}$ during at least one time point in the first 7 DIM, but RPC did not influence the incidence rate of SCH. This incidence rate is greater than that of $48 \%$ reported by Reinhardt et al. (2011), but cows in their study were sampled only 1 time within the first 48 $\mathrm{h}$ postcalving. Prevalence of $\mathrm{SCH}$, defined as tCa $<8.0$ $\mathrm{mg} / \mathrm{dL}$ in the first $7 \mathrm{DIM}$, was reduced by 15 percentage points during the first week postpartum ( 25.5 vs. $10.5 \%$ for $-\mathrm{RPC}$ vs. $+\mathrm{RPC}$, respectively; $P<0.01$; Table 6$)$, when cows were supplemented with RPC. The treat- 
ment difference in plasma tCa was significant only on d 0 and 3 postpartum (Figure 10), indicating that more cows had returned to Ca homeostasis in blood by 3 DIM if fed RPC. Supplemental choline may have improved Ca status through (1) improved activity of vitamin D (fat-soluble vitamin); (2) improved absorption of Ca or vitamin $\mathrm{D}$ if synthesis of intestinal chylomicrons was increased with additional PC; (3) increased mobilization of Ca from bone; or (4) increased retention of $\mathrm{Ca}$ by the kidney. For example, activity of CaATPase, which is involved in vitamin D-dependent active transport of $\mathrm{Ca}$, was reduced in absorptive cells of small intestine of rats fed a choline-deficient diet (Takahashi et al., 1982). The effects of RPC on Ca status are quite profound, and further research on potential effects of choline on Ca homeostasis may prove fruitful.

Supplementation with RPC did not influence the proportion of cows cycling by $40 \pm 3$ DIM (80.5 vs. $80.9 \%$ for $-\mathrm{RPC}$ and $+\mathrm{RPC}$ treatments, respectively). Feeding RPC tended to increase the proportion of cows pregnant at first AI $(P=0.09 ; 41.3$ vs. $23.6 \%)$ but not at 40 wk postpartum (69.8 vs. $62.5 \%$ ). The hazard of pregnancy for $+\mathrm{RPC}$ and $-\mathrm{RPC}$ cows was $1.29(95 \%$ $\mathrm{CI}=0.44$ to 1.35$)$. The number of days open were 143 versus $123 \mathrm{~d}$ for $-\mathrm{RPC}$ and $+\mathrm{RPC}$ groups, respectively. Cox's proportional analysis of average days to pregnancy from the end of the voluntary waiting period until 210 DIM indicated that treatments did not affect $(P=0.14)$ the rate at which cows became pregnant (Figure 11). Others have reported reproductive benefits from supplementing with RPC, such as improved pregnancy rate (29.0 vs. $58.1 \%$; $n=62$; Scheer Oelrichs, 2003), 33 fewer days open ( $=27$; Amrutkar et al., 2015), and a greater proportion of multiparous but not primiparous cows cycling by 61 DIM $(\mathrm{n}=333$; Lima et al., 2012); pregnancy was numerically but not statistically greater in these latter 2 studies. Supplemental choline may enhance the local production of apolipoproteins by ovarian granulosa cells, which may provide a protective effect through binding by the lipoproteins with LPS, thus preventing an inflammatory response within the ovary. Because ovarian granulosa cells produce apolipoproteins (Gautier et al. 2010), and because lipoproteins can bind to LPS (Vreugdenhil et al., 2001), supplemental choline may help minimize an inflammatory response with the ovary, resulting in a more robust oocyte for fertilization. Reduced inflammation through supplemental RPC may have contributed toward improved pregnancy. Although not significant, incidence of RFM, metritis, puerperal metritis, and endometritis were lower in cows fed RPC (Table 3). Cows with more uterine disease are less likely to become pregnant (Riberio et al., 2012). Relative transcription abundance of several cytokines were lower in blood cells stimulated

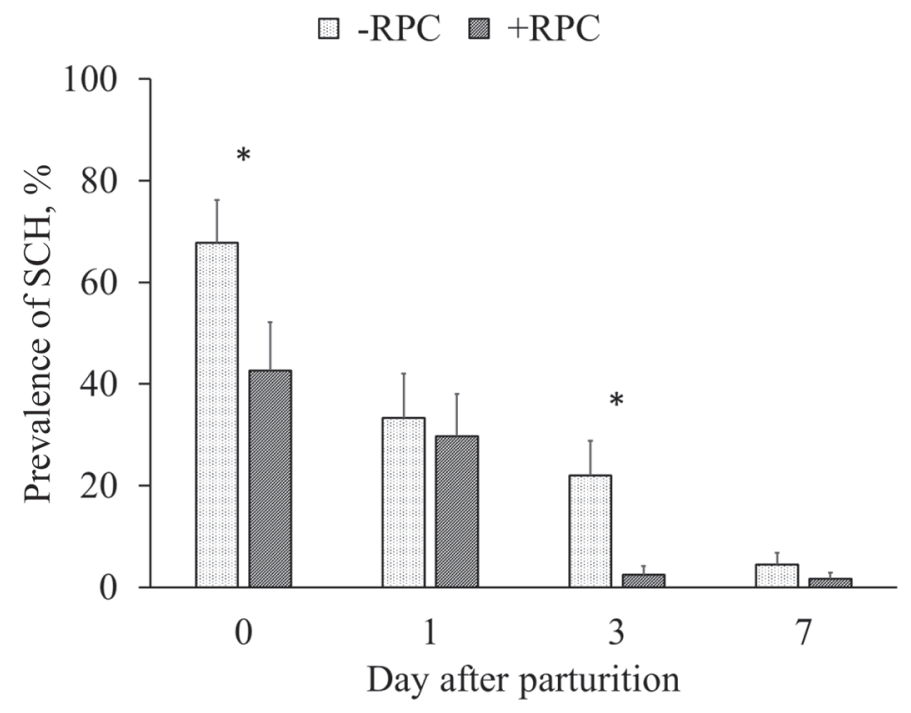

Figure 10. Effect of periparturient supplementation with or without ruminally protected choline $(+\mathrm{RPC}$ or $-\mathrm{RPC}$, respectively) on prevalence of subclinical hypocalcemia $(\mathrm{SCH})$. Effects of RPC $(P<$ $0.01)$ and $\mathrm{RPC} \times$ time interaction were detected $(P=0.05)$. At each day relative to parturition, differences between dietary treatments were found: ${ }^{*} P \leq 0.05$. Error bars represent SEM.

in vitro with LPS from cows fed RPC (Zenobi et al., 2017). Lima et al. (2012) reported that cows fed RPC had lower morbidity in a field study in which cows were fed RPC pre- and postpartum.

Yield of colostrum did not differ between $-\mathrm{RPC}$ and $+\mathrm{RPC}$ treatment groups (8.7 vs. $9.4 \mathrm{~kg}$, respectively;

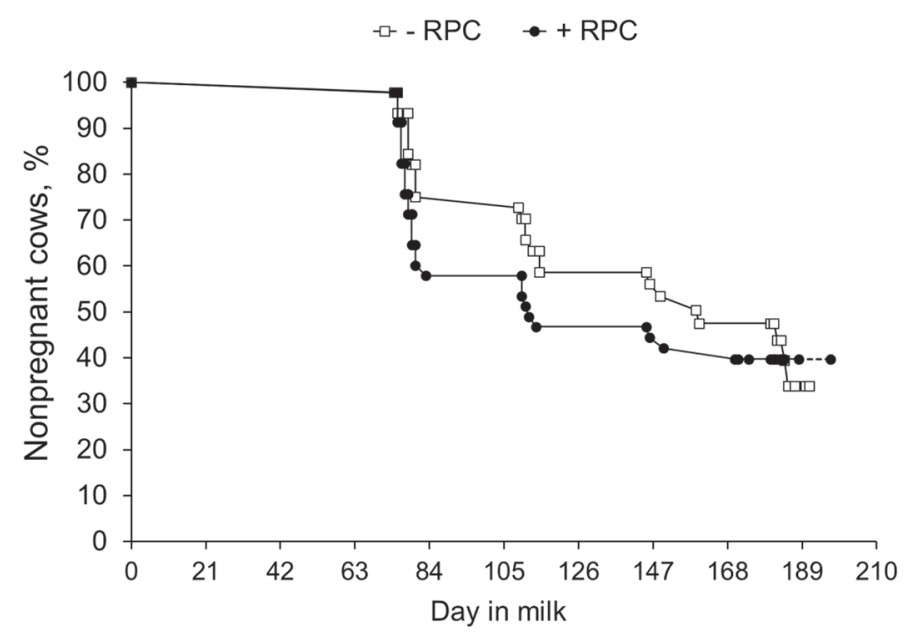

Figure 11. Survival curves for days to pregnancy up to 210 DIM for multiparous Holstein cows supplemented with or without ruminally protected choline (+RPC or $-\mathrm{RPC}$, respectively). Only cows synchronized and AI were included in the analysis $(\mathrm{n}=91)$. Effect of RPC $(P$ $=0.14$ ) was not detected. Average (143 vs. 123) and median (160 vs. 112) days to pregnancy for $-\mathrm{RPC}$ and $+\mathrm{RPC}$ treatments, respectively. Hazard ratio was $1.29(95 \% \mathrm{CI}=0.74-2.26)$. Pregnancy by $210 \mathrm{DIM}$ was 55.4 vs. $59.7 \%$ for $-\mathrm{RPC}$ vs $+\mathrm{RPC}$, respectively. 
Table 7); however, yield of IgG was greater (490 vs. $702 \mathrm{~g} /$ cow; $P=0.04$ ) due to numerically greater yield of colostrum and greater concentration of IgG in colostrum of cows fed RPC $(68.2$ vs. $86.9 \mathrm{~g} / \mathrm{L}, P=0.03$, respectively). The implications of increased intake of IgG on a calf's immune system and subsequent lactation performance needs further study.

Retrospective data were analyzed for the uterine effect of RPC (uterine effect) on performance of the offspring. Only 35 females were born in a single delivery ( $\mathrm{n}=17$ and 18 for $-\mathrm{RPC}$ vs. $+\mathrm{RPC}$, respectively) and were weighed at birth, weaning, and $300 \mathrm{~d}$ of age. Calves exposed in utero to a richer choline environment during the last $17 \mathrm{~d}$ of gestation tended $(P=0.07)$ to be lighter at birth (40.4 vs. $38.3 \mathrm{~kg}$ ) but weighed more by $300 \mathrm{~d}$ of age ( $335 \mathrm{vs} .321 \mathrm{~kg} ; P=0.05$; Table 7 ), which tended $(P=0.06)$ to result in a greater ADG from calving to $300 \mathrm{~d}$ of age $(0.81$ vs. $0.85 \mathrm{~kg} / \mathrm{d})$ compared with heifers born from cows not fed RPC (Table 7).

Work with rats demonstrated the benefits of feeding adequate amounts of lipotropes (choline, methionine, and vitamin $\mathrm{B}_{12}$ ) to the pregnant dam on the immunity of their pups. Offspring from dams fed diets deficient in lipotropes weighed less at birth and weaning than pups born from rats fed the diet adequate in lipotropes (Newberne et al., 1970). In addition, pup survival from Salmonella Typhimurium infection was not improved if pups were fed the lipotropes after birth compared with pups born to dams fed adequate amounts of lipotropes before and after parturition. In addition, choline supplementation during late gestation may improve gluconeogenesis, the most important metabolic pathway for endogenous glucose generation from substrates such as propionate, lactic acid, and gluconeogenic AA, after weaning. Cai et al. (2014) reported that supplementing sows throughout gestation with betaine (a metabolite of choline; $3 \mathrm{~g} / \mathrm{kg}$ of diet) improved hepatic gluconeogenesis in newborn piglets. Specifically, newborn piglets from betaine-supplemented sows had greater serum concentrations of lactic acid and gluconeogenic AA, including serine, glutamate, methionine, and histidine. In addition, liver tissue from these piglets contained greater glycogen concentration (0.16 vs. $0.13 \mathrm{~g} / \mathrm{g})$ and cytoplasmic phosphoenolpyruvate carboxykinase enzyme activity, as well as greater protein expression of several gluconeogenic enzymes, including pyruvate carboxylase, cytoplasmic phosphoenolpyruvate carboxykinase, mitochondrial phosphoenolpyruvate carboxykinase, and fructose-1,6-bisphosphatase, compared with control piglets. Feeding RPC during late gestation to pregnant ruminants may provoke changes in expression of gluconeogenic genes in the liver of preruminants, causing long-term positive effects in glucose homeostasis later in ruminant life.

\section{CONCLUSIONS}

Consuming calories at approximately $140 \%$ of requirement during the entire dry period did not affect BW or BCS at calving but did result in lower DMI and greater negative $\mathrm{EB}$ postpartum, resulting in greater circulating concentrations of fatty acids and BHB, greater concentration of liver TAG, and greater time to regain prepartum BW compared with cows fed energy to maintenance. Supplementation of $17.3 \mathrm{~g} / \mathrm{d}$ of choline chloride $(12.9 \mathrm{~g} / \mathrm{d}$ of choline ions) as RPC for approximately 3 wk before and 3 wk after parturition tended to improve yield of milk (15 and 40 wk postpartum) and milk components (15 wk postpartum) without affecting DMI. As a result, EB was more negative at wk 2 and 3 postpartum but without changes in plasma concentrations of fatty acids and BHB or liver TAG concentrations. Additional benefits of RPC supplementation included reduction in prevalence of SCH, improved conception at first AI, improved output of IgG in colostrum, and improved ADG of heifers through $300 \mathrm{~d}$ of age. These positive effects of RPC were independent of prepartum caloric intake. If these results are confirmed in future studies, the case for choline as an essential nutrient for high-producing ruminants will be strengthened.

\section{ACKNOWLEDGMENTS}

Rodrigo Moreira (Universidade Federal do Paraná, Curitiba, Brazil) and Camilo Lopera (University of Florida) helped ensure proper daily care of cows and collection of samples. Rodrigo Gardinal was supported by a Sao Paulo Research Foundation (Sao Paulo, Brazil) fellowship (\#2014/13132-5). Special thanks go to Sergei Sennikov (University of Florida) for help with laboratory assays. The experiment was partially supported by a grant from Balchem Animal Nutrition and Health (New Hampton, NY).

\section{REFERENCES}

Agenäs, S., E. Burstedt, and K. Holtenius. 2003. Effects of feeding intensity during the dry period. 1. Feed intake, body weight, and milk production. J. Dairy Sci. 86:870-882.

Allen, M. S., B. J. Bradford, and M. Oba. 2009. Board-invited review: The hepatic oxidation theory of the control of feed intake and its application to ruminants. J. Anim. Sci. 87:3317-3334.

Amrutkar, S. A., S. P. Pawar, S. S. Thakur, N. J. Kewalramani, and M. S. Mahesh. 2015. Dietary supplementation of rumen-protected methionine, lysine and choline improves lactation performance and blood metabolic profile of Karan-Fries cows. Agric. Res. 4:396-404.

Andersen, J. B., T. Larsen, M. O. Nielsen, and K. L. Ingvartsen. 2002. Effect of energy density in the diet and milking frequency on hepatic long chain fatty acid oxidation in early lactating dairy cows. J. Vet. Med. A Physiol. Pathol. Clin. Med. 49:177-183.

Asakuma, S., H. Morishita, T. Sugino, Y. Kurose, S. Kobayashi, and Y. Terashima. 2003. Circulating leptin response to feeding and 
exogenous infusion of insulin in sheep exposed to thermoneutral and cold environments. Comp. Biochem. Physiol. A Mol. Integr. Physiol. 134:329-335.

Baldi, A., and L. Pinotti. 2006. Choline metabolism in high-producing dairy cows: Metabolic and nutritional basis. Can. J. Anim. Sci. $86: 207-212$.

Bielmann, V., J. Gillan, N. R. Perkins, A. L. Skidmore, S. Godden, and K. E. Leslie. 2010. An evaluation of Brix refractometry instruments for measurement of colostrum quality in dairy cattle. J. Dairy Sci. 93:3713-3721.

Bobe, G., J. W. Young, and D. C. Beitz. 2004. Invited review: Pathology, etiology, prevention, and treatment of fatty liver in dairy cows. J. Dairy Sci. 87:3105-3124.

Boisclair, Y., D. G. Grieve, J. B. Stone, B. Allen, and G. K. Macleod. 1986. Effect of prepartum energy, body condition, and sodium bicarbonate on production of cows in early lactation. J. Dairy Sci. 69:2636-2647.

Bremer, J. 1983. Carnitine-Metabolism and functions. Physiol. Rev. 63:1420-1480.

Cai, D., Y. Jia, H. Song, S. Sui, J. Lu, Z. Jiang, and R. Zhao. 2014. Betaine supplementation in maternal diet modulates the epigenetic regulation of hepatic gluconeogenic genes in neonatal piglets. PLoS One 9:e105504.

Carlson, D. B., J. W. McFadden, A. D'Angelo, J. C. Woodworth, and J. K. Drackley. 2007. Dietary L-carnitine affects periparturient nutrient metabolism and lactation in multiparous cows. J. Dairy Sci. 90:3422-3441.

da Silva, R. P., K. B. Kelly, E. D. Lewis, K. A. Leonard, S. Goruk, J. M. Curtis, D. F. Vine, S. D. Proctor, C. J. Field, and R. L. Jacobs. 2015. Choline deficiency impairs intestinal lipid metabolism in the lactating rat. J. Nutr. Biochem. 26:1077-1083.

Douglas, G. N., T. R. Overton, H. G. Bateman II, H. M. Dann, and J. K. Drackley. 2006. Prepartal plane of nutrition, regardless of dietary energy source, affects periparturient metabolism and dry matter intake in Holstein cows. J. Dairy Sci. 89:2141-2157.

Drackley, J. K. 1999. Biology of dairy cows during the transition period: the final frontier. J. Dairy Sci. 82:2259-2273.

Drackley, J. K., R. L. Wallace, D. Graugnard, J. Vasquez, B. F. Richards, and J. J. Loor. 2014. Visceral adipose tissue mass in nonlactating dairy cows fed diets differing in energy density. J. Dairy Sci. 97:3420-3430.

Dubuc, J., T. F. Duffield, K. E. Leslie, J. S. Walton, and S. J. LeBlanc. 2010. Definitions and diagnosis of postpartum endometritis in dairy cows. J. Dairy Sci. 93:5225-5233.

Elanco Animal Health. 2009. The 5-point body condition scoring system. Bulletin AI 10752. Elanco Animal Health, Greenfield, IN.

Elek, P., T. Gaál, and F. Husvéth. 2013. Influence of rumen-protected choline on liver composition and blood variables indicating energy balance in periparturient dairy cows. Acta Vet. Hung. 61:59-70.

Folch, J., M. Lees, and G. H. Sloane Stanley. 1957. A simple method for the isolation and purification of total lipids from animal tissues. J. Biol. Chem. 226:497-509.

Foster, L. B., and R. T. Dunn. 1973. Stable reagents for determination of serum triglycerides by a colorimetric Hantzsch condensation method. Clin. Chem. 19:338-340.

Gaal, T., I. M. Reid, R. A. Collins, C. J. Roberts, and B. V. Pike. 1983. Comparison of biochemical and histological methods of estimating fat content of liver of dairy cows. Res. Vet. Sci. 34:245-248.

Gautier, T., S. Becker, V. Drouineaud, F. Ménétrier, P. Sagot, J. R. Nofer, S. von Otte, L. Lagrost, D. Masson, and U. J. Tietge. 2010. Human luteinized granulosa cells secrete apoB100-containing lipoproteins. J. Lipid Res. 51:2245-2252.

Gilbert, R. O., S. T. Shin, C. L. Guard, H. N. Erb, and M. Frajblat. 2005. Incidence of endometritis and its effects on reproductive performance of dairy cows. Theriogenology 64:1879-1888.

Gochman, N., and J. M. Schmitz. 1972. Application of a new peroxide indicator reaction to the specific automated determination of glucose with glucose oxidase. Clin. Chem. 18:943-950.

Goselink, R. M. A., J. van Baal, H. C. A. Widjaja, R. A. Dekker, R. L. G. Zom, M. J. deVeth, and A. M. van Vuuren. 2013. Effect of rumen-protected choline supplementation on liver and adipose gene expression during the transition period in dairy cattle. J Dairy Sci. 96:1102-1116.

Graugnard, D. E., M. Bionaz, E. Trevisi, K. M. Moyes, J. L. SalakJohnson, R. L. Wallace, J. K. Drackley, G. Bertoni, and J. J. Loor. 2012. Blood immunometabolic indices and polymorphonuclear function in peripartum dairy cows are altered by level of dietary energy prepartum. J. Dairy Sci. 95:1749-1758.

Graugnard, D. E., K. M. Moyes, E. Trevisi, M. J. Khan, D. Keisler, J. K. Drackley, G. Bertoni, and J. J. Loor. 2013. Liver lipid content and inflammometabolic indices in peripartal dairy cows are altered in response to prepartal energy intake and postpartal intramammary inflammatory challenge. J. Dairy Sci. 96:918-935.

Grum, D. E., J. K. Drackley, L. R. Hansen, and J. D. Cremin. 1996. Production, digestion, and hepatic lipid metabolism of dairy cows fed increased energy from fat or concentrate. J. Dairy Sci. 79:18361849 .

Grummer, R. R., D. G. Mashek, and A. Hayirli. 2004. Dry matter intake and energy balance in the transition period. Vet. Clin. North Am. Food Anim. Pract. 20:447-470.

Holcomb, C. S., H. H. Van Horn, H. H. Head, M. B. Hall, and C. J. Wilcox. 2001. Effects of prepartum dry matter intake and forage percentage on postpartum performance of lactating dairy cows. J. Dairy Sci. 84:2051-2058.

Holtenius, K., S. Agenas, C. Delavaud, and Y. Chilliard. 2003. Effects of feeding intensity during the dry period. 2. Metabolic and hormonal responses. J. Dairy Sci. 86:883-891.

Houseknecht, K. L., C. A. Baile, R. L. Matteri, and M. E. Spurlock 1998. The biology of leptin:A review. J. Anim. Sci. 76:1405-1420.

Janovick, N. A., Y. R. Boisclair, and J. K. Drackley. 2011. Prepartum dietary energy intake affects metabolism and health during the periparturient period in primiparous and multiparous Holstein cows. J. Dairy Sci. 94:1385-1400.Janovick. N. A., and J. K. Drackley. 2010. Prepartum dietary management of energy intake affects postpartum intake and lactation performance by primiparous and multiparous Holstein cows. J. Dairy Sci. 93:3086-3102.

Janovick Guretzky, N. A., D. B. Carlson, J. E. Garrett, and J. K. Drackley. 2006. Lipid metabolite profiles and milk production for Holstein and Jersey cows fed rumen-protected choline during the periparturient period. J. Dairy Sci. 89:188-200.

Ji, P., J. S. Osorio, J. K. Drackley, and J. J. Loor. 2012. Overfeeding a moderate energy diet prepartum does not impair bovine subcutaneous adipose tissue insulin signal transduction and induces marked changes in peripartal gene network expression. J. Dairy Sci. 95:4333-4351.

Johnson, M. M., and J. P. Peters. 1993. Technical note: An improved method to quantify nonesterified fatty acids in bovine plasma. J. Anim. Sci. 71:753-756.

Jørgensen, E., and A. R. Pedersen. 1998. How to obtain those nasty standard errors from transformed data-And why they should not be used. Biometry Res. Unit, Int. Rep. 7. Danish Inst. Ag. Sci., Aarhus, Denmark.

Kunz, P. L., J. W. Blum, I. C. Hart, H. Bickel, and J. Landis. 1985 Effects of different energy intakes before and after calving on food intake, performance and blood hormones and metabolites in dairy cows. Anim. Prod. 40:219-231.

Labarca, C., and K. Paigen. 1980. A simple, rapid, and sensitive DNA assay procedure. Anal. Biochem. 102:344-352.

Lima, F. S., R. S. Bisinotto, E. S. Ribeiro, L. F. Greco, H. Ayres, M. G. Favoreto, M. R. Carvalho, K. N. Galvão, and J. E. P. Santos. 2013. Effects of one or two treatments with prostaglandin $F_{2 \alpha}$ on subclinical endometritis and fertility in lactating dairy cows inseminated by timed AI. J. Dairy Sci. 96:6480-6488.

Lima, F. S., M. F. Sa Filho, L. F. Greco, and J. E. P. Santos. 2012 Effects of feeding rumen-protected choline on incidence of diseases and reproduction of dairy cows. Vet. J. 193:140-145.

Mann, S., F. L. Yepes, T. R. Overton, A. L. Lock, S. V. Lamb, J. J. Wakshlag, and D. V. Nydam. 2016. Effect of dry period dietary energy level in dairy cattle on volume, concentrations of immunoglobulin G, insulin, and fatty acid composition of colostrum. J. Dairy Sci. 99:1515-1526. 
Mann, S., F. L. Yepes, T. R. Overton, J. J. Wakshlag, A. L. Lock, C. M. Ryan, and D. V. Nydam. 2015. Dry period plane of energy: Effects on feed intake, energy balance, milk production, and composition in transition dairy cows. J. Dairy Sci. 98:3366-3382.

Marsh, W. H., B. Fingerhut, and H. Miller. 1965. Automated and manual direct methods for the determination of blood urea. Clin. Chem. 11:624-627.

McArt, J. A. A., D. V. Nydam, and G. R. Oetzel. 2012. Epidemiology of subclinical ketosis in early lactation dairy cattle. J. Dairy Sci. 95:5056-5066.

Mohsen, M. K., H. M. A. Gaafar, M. M. Khalafalla, A. A. Shitta, and A. M. Yousif. 2011. Effect of rumen protected choline supplementation on digestibility, rumen activity, and milk yield in lactating Friesian cows. Slovak J. Anim. Sci. 44:13-20.

Morrow, D. A. 1976. Fat cow syndrome. J. Dairy Sci. 59:1625-1629.

Newberne, P. M., R. B. Wilson, and G. Williams. 1970. Effects of severe and marginal maternal lipotrope deficiency on response of postnatal rats to infection. Br. J. Exp. Pathol. 51:229.

NRC. 2001. Nutrient Requirements of Dairy Cattle. 7th rev. ed. Natl. Acad. Press, Washington, DC.

Oetzel, G. R. 2004. Monitoring and testing dairy herds for metabolic disease. Vet. Clin. North Am. Food Anim. Pract. 20:651-674.

Orth, R. 1992. Sample day and lactation report. DHIA 200 Fact Sheet A-2. Mid-States DRPC, Ames, IA.

Piepenbrink, M. S., and T. R. Overton. 2003. Liver metabolism and production of cows fed increasing amounts of rumen-protected choline during the periparturient period. J. Dairy Sci. 86:1722-1733.

Pinotti, L., A. Baldi, I. Politis, R. Rebucci, L. Sangalli, and V. Dell Orto. 2003. Rumen-protected choline administration to transition cows: Effects on milk production and vitamin E status. J. Vet. Med. A Physiol. Pathol. Clin. Med. 50:18-21.

Reinhardt, T. A., J. D. Lippolis, B. J. McCluskey, J. P. Goff, and R. L. Horst. 2011. Prevalence of subclinical hypocalcemia in dairy herds. Vet. J. 188:122-124.

Ribeiro, E. S., A. P. A. Monteiro, F. S. Lima, H. Ayres, R. S. Bisinotto, M. Favoreto, L. F. Greco, R. S. Marsole, W. W. Thatcher, and J. E. P. Santos. 2012. Effects of presynchronization and length of proestrus on fertility of grazing dairy cows subjected to a 5-day timed artificial insemination protocol. J. Dairy Sci. 95:2513-2522.

Rukkwamsuk, T., T. Wensing, and M. J. H. Geelen. 1998. Effect of overfeeding during the dry period on regulation of adipose tissue metabolism in dairy cows during the periparturient period. J. Dairy Sci. 81:2904-2911.

Santos, J. E. P., and F. S. Lima. 2009. Feeding rumen-protected choline to transition dairy cows. Pages 149 to 159 in Proc. 20th Ann. Florida Ruminant Nutr. Symp. Univ. Florida, Gainesville.

Scheer Oelrichs, W. A. 2003. The effects of feeding soybeans and rumen protected choline during the periparturient period and early lactation on production and reproduction of dairy cows. PhD Diss. Univ. Missouri, Columbia.

Shahsavari, A., M. J. D'Occhio, and R. Al Jassim. 2016. The role of rumen-protected choline in hepatic function and performance of transition dairy cows. Br. J. Nutr. 116:35-44.
Sheldon, I. M., G. S. Lewis, S. LeBlanc, and R. O. Gilbert. 2006 Defining postpartum uterine disease in cattle. Theriogenology 65:1516-1530.

Soltan, M. A., A. M. Mujalli, M. A. Mandour, and M. El-Shinway Abeer. 2012. Effect of dietary rumen protected methionine and/ or choline supplementation on rumen fermentation characteristics and productive performance of early lactating cows. Pak. J. Nutr. 11:221-230.

Sun, F., Y. Cao, C. Cai, S. Li, C. Yu, and J. Yao. 2016. Regulation of nutritional metabolism in transition dairy cows: Energy homeostasis and health in response to post-ruminal choline and methionine. PLoS One 11:e0160659.

Takahashi, Y., T. Mizunuma, and Y. Kishino. 1982. Ultracytochemical studies on fat absorption by choline-deficient rats. Acta Histochem. Cytochem. 15:90-101.

Vreugdenhil, A. C., A. P. Snoek, C. van't Veer, J. W. M. Greve, and W. A. Buurman. 2001. LPS-binding protein circulates in association with apoB-containing lipoproteins and enhances endotoxinLDL/VLDL interaction. J. Clin. Invest. 107:225-234.

Winkelman, L. A., T. H. Elsasser, and C. K. Reynolds. 2008. Limit-feeding a high-energy diet to meet energy requirements in the dry period alters plasma metabolite concentrations but does not affect intake or mil production in early lactation. J. Dairy Sci. 91:1067-1079.

Zahra, L. C., T. F. Duffield, K. E. Leslie, T. R. Overton, D. Putnam, and S. J. LeBlanc. 2006. Effects of rumen-protected choline and monensin on milk production and metabolism of periparturient dairy cows. J. Dairy Sci. 89:4808-4818.

Zeisel, S. H. 1991. Choline, an essential nutrient for humans. FASEB J. 5:2093-2098.

Zenobi, M. G., A. M. Lopez, J. E. Zuniga, C. D. Nelson, J. P. Driver, K. C. Jeong, R. A. Mir, B. A. Barton, J. E. P. Santos, and C. R. Staples. 2017. Prepartum energy intake and supplementation of rumen-protected choline (RPC) influence biomarkers of the immune system of lactating dairy cows. J. Dairy Sci. 100(Suppl 2):407. (Abstr.)

Zhang, Q., H. Su, F. Wang, Z. Cao, and S. Li. 2015. Effects of energy density in close-up diets and postpartum supplementation of extruded full-fat soybean on lactation performance and metabolic and hormonal status of dairy cows. J. Dairy Sci. 98:7115-7130.

Zhou, Z., M. Vailati-Riboni, E. Trevisi, J. K. Drackley, D. N. Luchini, and J. J. Loor. 2016. Better postpartal performance in dairy cows supplemented with rumen-protected methionine compared with choline during the peripartal period. J. Dairy Sci. 99:8716-8732.

Zom, R. L., G. J. Van Baal, R. M. A. Goselink, J. A. Bakker, M. J. De Veth, and A. M. Van Vuuren. 2011. Effect of rumen-protected choline on performance, blood metabolites, and hepatic triacylglycerols of periparturient dairy cattle. J. Dairy Sci. 94:4016-4027. 